\title{
THE ORGANISATION OF DRILL PRODUCTION AT A NEOLITHIC LITHIC WORKSHOP SITE OF BAI BEN, CAT BA ISLAND, VIETNAM
}

\author{
Dong Truong Nguyen ${ }^{1,2}$ and Chris Clarkson ${ }^{2}$ \\ ${ }^{1}$ Vietnamese Institute of Archaeology, Hanoi, Vietnam, ${ }^{2}$ School of Social Science, The University of Queensland \\ Email: truongdong@hotmail.com, c.clarkson@uq.edu.au
}

\begin{abstract}
We investigate stone drill point production, use, maintenance, and discard from a technological perspective at the Late Neolithic workshop of Bai Ben on Cat Ba Island, Northeastern Vietnam. Bai Ben contains over 18,000 retouched chert flakes classified as drill points and dating to c. 3000BP. Large scale production of drills most likely took place for reasons of mass production of drilled organic and inorganic objects. Few such drilled objects are found at the site, perhaps due to poor organic preservation or removal of finished objects for trade and exchange. An analysis of attributes on drills and cores examines the time-ordering of dimensional and morphological changes as reduction continued at the site. The research finds that drills were produced from a diverse range of nodules sizes, blanks, core technologies and raw materials, but similar blanks were selected to produce very similar drill point forms.
\end{abstract}

\section{INTRODUCTION}

One of the most interesting and attractive discoveries of Vietnamese archaeology in 1999 was a very large lithic artefact assemblage of more than 18,000 finished and unfinished chert drill points, over 200,000 flakes and debitage, and about 265 cores unearthed from a late Neolithic workshop site of Bai Ben, dated at over 3000 BP (Dong 2000) (Figures 1 and 2). The quantity of lithic artefacts indicates that this is unambiguously a workshop specialising in drill point manufacture. Although bored or drilled products are uncommon at Bai Ben, and no studies of usewear or residues have yet been undertaken, morphological comparisons and observations between the Bai Ben drills and those known from California (Arnold, 1987), Mississippi (Yerkes, 1983), Turkey (Calley \& Grace, 1988), Israel (Rosen, 1995), Iran (Piperno, 1973), Papua New Guinea (Allen, Holdaway, \& Fullagar, 1997) and Vietnam (Dung, 1996) show close similarity in form and edge damage patterns (Dong, 2008a), suggesting these are indeed points used for drilling through hard materials.

Functional issues aside, this paper aims only to address the question of how these chert drill points were made as well as the over-arching organisation of lithic technology at the site. We therefore investigate how raw materials were acquired, how flakes were detached from cores, what criteria were employed for drill blank selection, and how drills were made and discarded. We first present the conceptual framework and the methodology employed, followed by a review of some key features of the Bai Ben site. We then explore core reduction at the site and the reduction sequence for the drills themselves.

\section{The Site of Bai Ben}

Bai Ben site is located on the north-eastern Vietnamese coast in a karstic landscape covered by the Holocene marine transgression (Thanh, 1998). The archaeological record of this maritime region can be traced back to at least the late Pleistocene. The earliest known Soi Nhu culture lasted from the Upper Paleolithic to Early Neolithic (about 25,000 to 7,000 years ago), followed by the Middle Neolithic culture of Cai Beo (roughly 7,000 to 5,000 BP), and finally by the Late Neolithic culture of Ha Long (from about 5,000 to 3,000 BP) to which the Bai Ben site belongs (Nga \& Hao, 1998). This cultural sequence creates a continuous record of cultural change in the area.

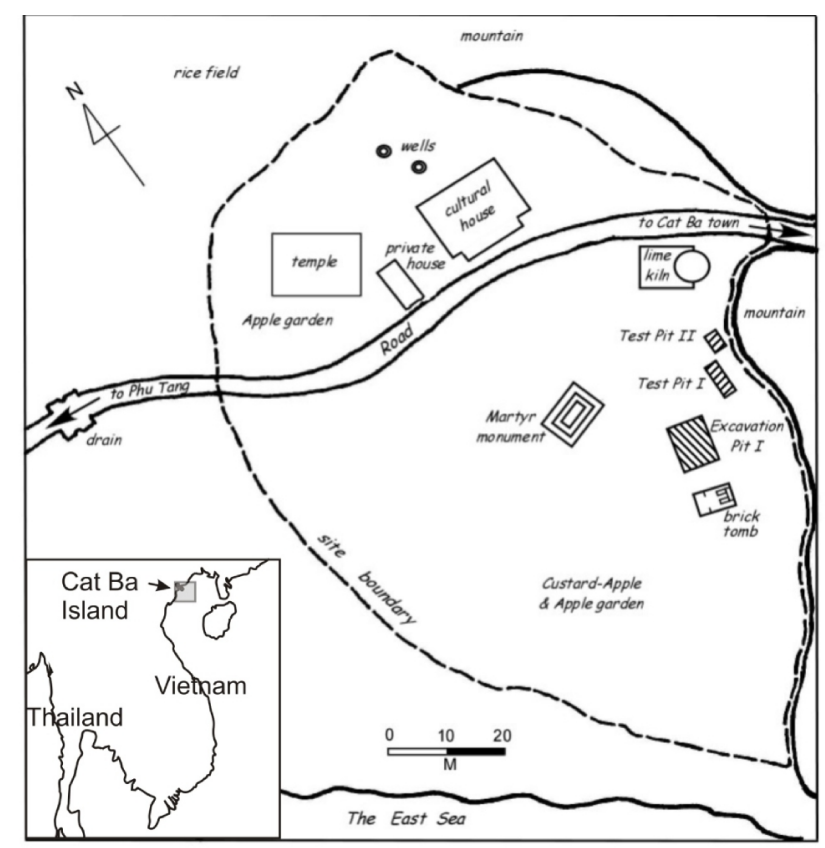

Figure 1: The location and site plan of Bai Ben. 


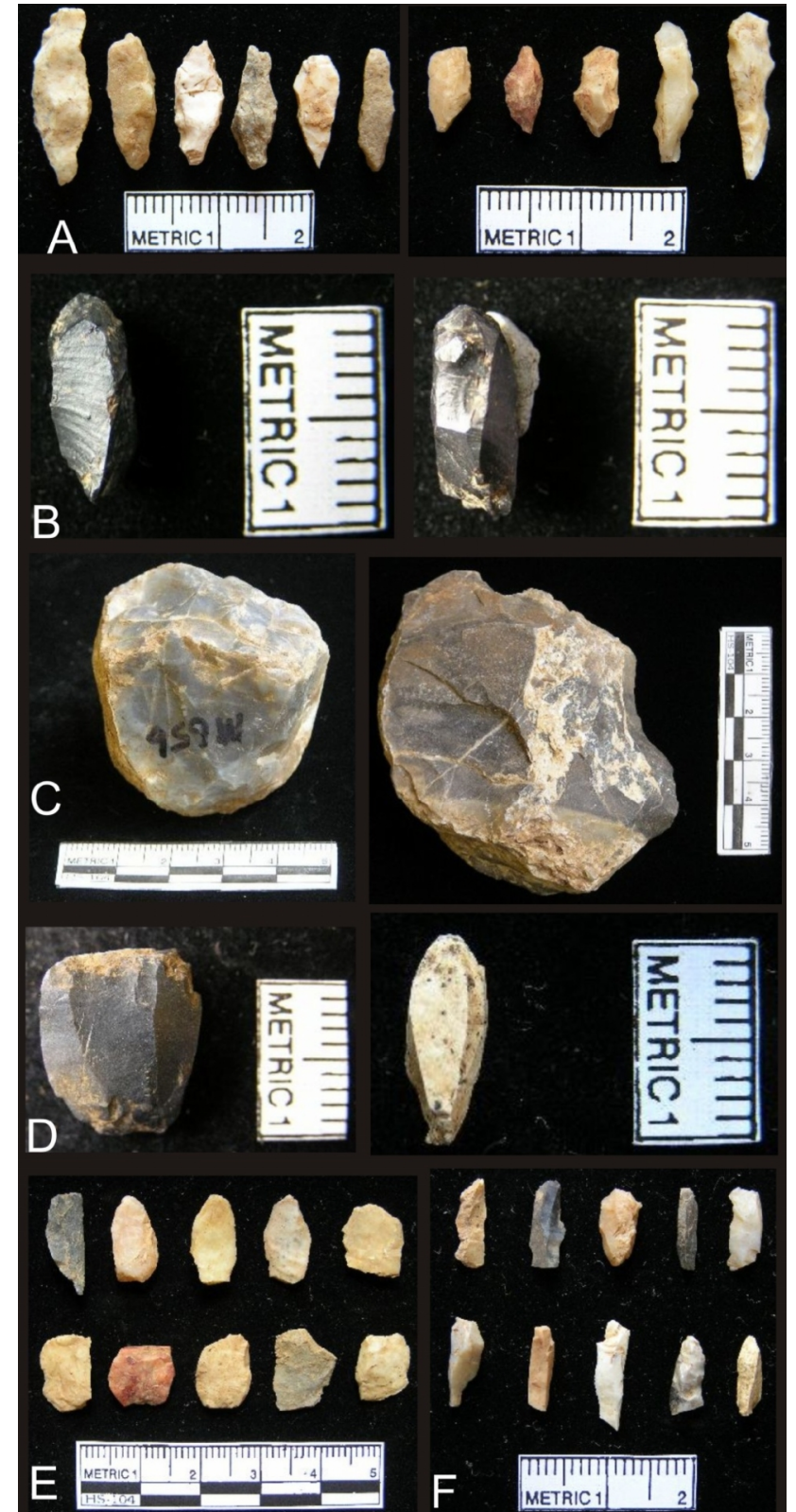

Figure 2: Flaked artefact types found at Bai Ben. A: drills made on flakes, $B$ : drills made on small bipolar cores, $C$ : freehand cores, D: bipolar cores; E: flakes from freehand cores, $F$ : microblades from freehand and bipolar cores.

Bai Ben itself is located in the south-western corner of Cat Ba Island within Ha Long Bay and about 50km from the mainland. Ha Long Bay is a well-known region and is recognised as a UNESCO World Natural Heritage area (Figure 3). Bai Ben is an open site, close to the sea, situated on a relatively large and flat sandbank in the windprotected area of Cat Ba Island - a place long used for both mooring boats and fishing. The site is estimated to have once been some $5000 \mathrm{~m}^{2}$ in area, but much of it has been destroyed by human activities such as war memorial statue construction, house building, road making, and sand mining (Figure 2). An area of $142.5 \mathrm{~m}^{2}$ has been so far excavated over two seasons in 1999 and 2001. Excavations at Bai Ben have consistently yielded a single cultural layer of about $80 \mathrm{~cm}$ in thickness (Figure 3 ).

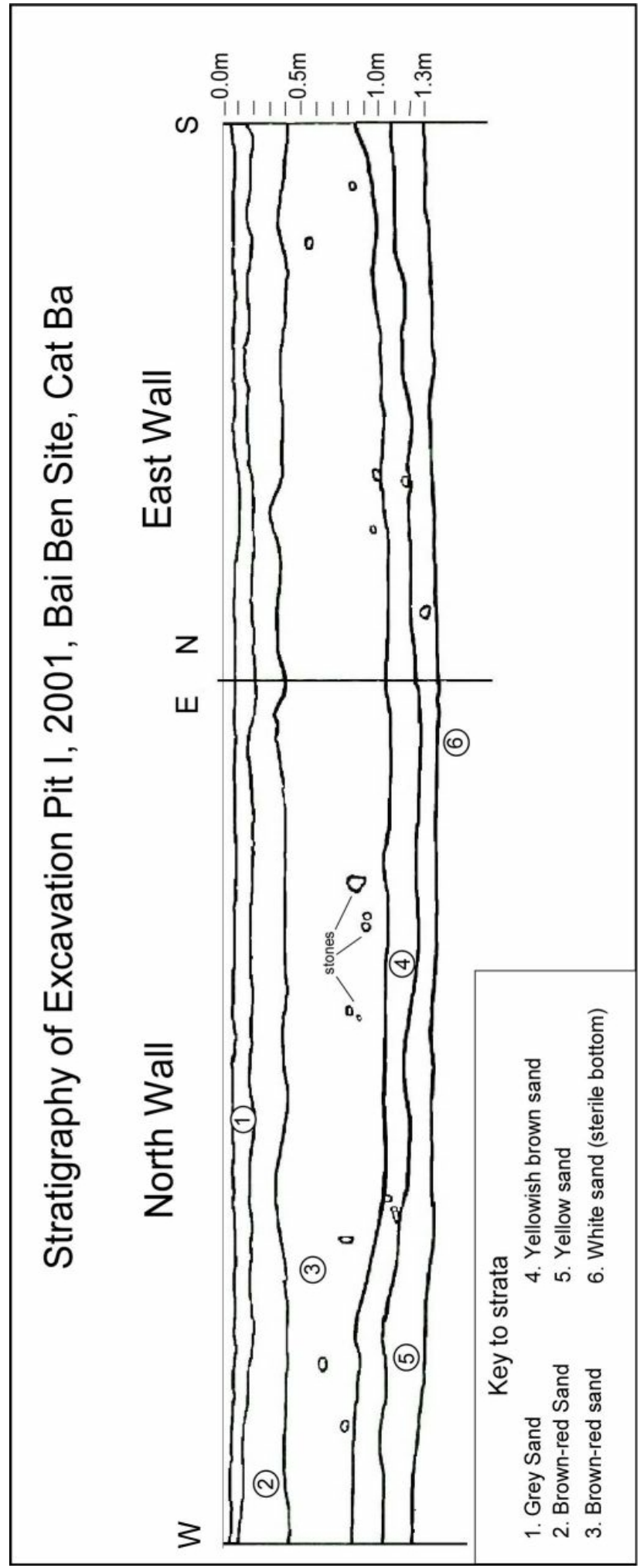

Figure 3: The stratigraphy of Bai Ben site.

Sand is the primary component of the deposit. This occupational layer has been disturbed in some places by the activities of the local cemetery. However, stratigraphic disturbance occurs only from the surface down to a depth of about $60 \mathrm{~cm}$. From $80 \mathrm{~cm}$ downward, the stratigraphy is intact (Dung, Buong, Phuong, \& Dong, 2001). 
The Bai Ben site sits within the Late Neolithic period of the 'Ha Long Culture' that is recognised by the presence of diagnostic ground shoulder and/or stepped axes/adzes and pottery. Several $\mathrm{C}_{14}$ dates obtained from mollusc shells provide ages consistent with a late Neolithic association and demonstrate the likely short period of accumulation of most cultural materials at the site (Table 1).

Table 1: ${ }^{14}$ C ages for the Bai Ben site.

\begin{tabular}{lll} 
Relative Date & ${ }^{14} \mathrm{C}$ dates & Strata \\
\hline & $3180 \pm 55$ BP (HNK-87) & Sterile bottom \\
Late Neolithic & $3380 \pm 55$ BP (HNK-91) & Sterile bottom \\
& $3900 \pm 80$ BP (HNK-92) & Layer 4 \\
& $3150 \pm 55$ BP (HNK-86) & Layer 4 \\
\hline
\end{tabular}

In addition to the large numbers of drill points, cores, and flakes, Bai Ben has also yielded a certain number of ground basalt shouldered and/or stepped or rectangular axes/adzes, sandstone saw blades, chert ground/flaked pointed tools, grinding stones, stone hammers, anvils, a stone spear head, a small number of ornaments including slate and nephrite beads and bracelet fragments. The site has also yielded some bronze artefacts such as axes, seals, coins, and bronze waste dated to later periods.

\section{METHODS}

To fulfil the objectives of this study, a technological analysis was performed on the Bai Ben assemblage, with particular emphasis on the reconstruction of reduction sequences for cores and drills. Three main aspects of the technological approach are briefly described below, encompassing the concept of sequence models, classification, and artefact description and attribute selection.

Sequence models are defined by Hiscock (1993:65) as "a description of the order in which reduction occurs within one block of stone", and by Bleed (2001:102) as "the operation of activities that progress through time". Sequence models are a heuristic device that enables description of the time ordering of manufacturing actions employed in the reduction of cores and the manufacture and resharpening of drills. Constructing a reduction sequence requires tracking dimensional and morphological changes over the use life of artefacts by ordering them according to some measure of reduction intensity. A number of reduction measures are in current use in lithic studies, but reduction measures must be carefully chosen to ensure they are best suited to the material under study. For drill points we found Clarkson's Index of Invasiveness (2002) the most useful as a measure of scar coverage and invasiveness across a number of surfaces, from unifacial through to complex hexi-facial artefacts. For core reduction we mostly rely on size and mass as measures of reduction, acknowledging that these are not ideal measures of reduction (see Clarkson in press).

A number of attributes that are sensitive to the effects of reduction were chosen for analysis on flakes, cores and drill points. Size variables include length, width, thickness, and weight. Technological variables include those related to the striking platform, dorsal/negative surfaces, and cortex. The analysed sample from Bai Ben consisted of 757 cores, 510 flakes and 806 drill points. We begin our analysis with consideration of the procurement and differential treatment of raw materials at the site.

\section{RESULTS}

\section{Raw Material Procurement}

The identification of the origin and type of stone materials used at Bai Ben plays an important role in understanding the human behaviour in tool manufacture, use, maintenance, and discard. Stone artefacts found at Bai Ben are predominantly made from two raw materials, chert and quartz, with chert being the dominant material. While no specialist sourcing analysis has so far been undertaken for Bai Ben cherts, geological literature documents the occurrence of chert as interbedded inclusions within local limestone formations (Thanh 1998:26-27). The chert materials from Bai Ben exhibit a wide range of forms and cortex types indicative of materials being obtained from a variety of landscape settings. The local availability of chert was probably a key factor driving the use of Bai Ben as a drill production workshop.

\section{Core Reduction and the Organisation of Flake Produc- tion}

The purpose of the study of core reduction is to identify the strategies by which appropriate flakes were generated from a variety of raw material and core types. Three types of cores are present in the Bai Ben assemblage, these are freehand, bipolar, and pressure cores. All three kinds were used to produce blanks suitable for drill point production (Dong, 2000; 2001; 2006; 2007; 2008a; 2008b; 2008c; 2008d; Dong et al. 2000). A question arises as to whether these reduction strategies, particularly the freehand and bipolar, are separate and independent reduction strategies or represent stages in a single reduction continuum. If core types represent different stages in a reduction sequence, then the dimensions of cores and flakes should be significantly different. The tables below present comparisons of the dimensions between bipolar and freehand cores, and between bipolar and pressure flaked cores.

A total number of 661 freehand and bipolar cores and 56 bipolar and pressure ones, which are all unbroken and made on chert, are included in this comparison. It is noted that 28 bipolar cores in this test sample are of smallest weight with a view to keeping their values normally distributed and closest to pressure ones' values. T-test results shown in Tables 2 and 3 indicate that the difference in all artefact dimensions between freehand and bipolar cores, and between bipolar and pressure flaked bipolar cores are 
Table 2: Dimensional comparisons between freehand and bipolar cores

\begin{tabular}{llllllll}
\hline & Core Types & $\mathrm{N}$ & Mean & Std. Deviation & t-value & $\mathrm{df}$ & $\mathrm{p}$ \\
\hline Weight $(\mathrm{g})$ & Bipolar & 521 & 3.93 & 7.12559 & -26.972 & 659 & .000 \\
& Freehand & 140 & 54.42 & 40.53709 & & & \\
Length $(\mathrm{cm})$ & Bipolar & 521 & 1.79 & 0.73503 & -22.793 & 659 & .000 \\
& Freehand & 140 & 3.81 & 1.43805 & & & \\
Width $(\mathrm{cm})$ & Bipolar & 521 & 1.26 & 0.64049 & -29.730 & 659 & .000 \\
& Freehand & 140 & 3.46 & 1.15778 & & \\
Thickness $(\mathrm{cm})$ & Bipolar & 521 & 0.77 & 0.46594 & -26.900 & 695 & .000 \\
& Freehand & 140 & 2.32 & 0.96228 & & & \\
\hline
\end{tabular}

Table 3: Dimensional comparisons between bipolar and pressure flaked cores

\begin{tabular}{|c|c|c|c|c|c|c|c|}
\hline Cores Types & & Mean & $\mathrm{N}$ & Std. Deviation & t-value & df & $\mathrm{p}$ \\
\hline \multirow[t]{2}{*}{ Weight (g) } & Pressure & 0.15 & 28 & 0.05588 & $\begin{array}{l}-7.853 \\
\end{array}$ & 27 & .000 \\
\hline & Bipolar & 1.39 & 28 & 0.83724 & & & \\
\hline \multirow[t]{2}{*}{ Length $(\mathrm{cm})$} & Pressure & 0.93 & 28 & 0.16079 & -10.738 & 27 & .000 \\
\hline & Bipolar & 1.54 & 28 & 0.30747 & & & \\
\hline \multirow[t]{2}{*}{ Width $(\mathrm{cm})$} & Pressure & 0.38 & 28 & 0.07900 & -12.988 & 27 & .000 \\
\hline & Bipolar & 1.10 & 28 & 0.29190 & & & \\
\hline \multirow[t]{2}{*}{ Thickness (cm) } & Pressure & 0.32 & 28 & 0.05711 & -7.893 & 27 & .000 \\
\hline & Bipolar & 0.60 & 28 & 0.15640 & & & \\
\hline
\end{tabular}

(Note: only including bipolar cores with smallest weight to prevent outliers and to be close to the pressure flaked cores'values)

significant. The diminishing but overlapping size of free hand, bipolar, and pressure flaked cores can be seen in Figure 4 and indicate that these modes of core reduction could represent different stages in a single technological chain at Bai Ben, with freehand cores representing initial reduction and pressure flaked cores the final stage in the technological sequence. However, it is also possible that cores could have begun reduction using any one of these strategies. This might occur when different sized nodules required different reduction techniques to effectively produce flakes. When nodules are very small, for instance, people may have begun reduction using bipolar methods. This is demonstrated by the fact that at least three bipolar cores retain a considerable amount of cortex (41-70\%) and the original pebbles are small in size, which are illustrated as three bold dashes located at the end of the graph (Figure 5).

If all cores represent stages along a single reduction continuum, then more reduced cores should be smaller than less reduced ones. This might be measured as an increasing numbers of flake scars, an increasing number of striking platforms and less remaining cortex as reduction intensifies. In fact, both freehand and bipolar cores show quite the opposite pattern (Figures 6 and 7) in that the more highly reduced cores (i.e., greater numbers of flake scar, volume, platforms and cortex percentage) are not dimensionally smaller, but significantly larger than less reduced ones. This pattern might be explained in terms of raw material selection, initial size and availability.

Varying sizes of raw material introduced into the site could have contributed considerably to the pattern seen in core morphologies and dimensions. Figure 8 shows that very small freehand and bipolar cores can have very large amounts of cortex. This may have caused people to have initiated core reduction using the bipolar method on small pieces of raw material. Furthermore, there is evidence of strategy switching from freehand to bipolar reduction (Figure 9). Freehand cores overlap with bipolar cores at the smaller end of the mass continuum, indicating that freehand cores could have switched to bipolar cores once they fell below 100g. This suggests that large freehand cores might continue to be reduced as freehand cores until they were discarded, or they may swap to bipolar reduction below about $100 \mathrm{~g}$. Bipolar cores may start out either as small nodules or as larger freehand cores (Figure 11).

Mean values of two flake assemblages that are complete, made on chert and evident with striking platform, consisting of 6 bipolar flakes identified as those with crushed termination and 45 freehand ones identified as those with non-crushed termination offers support for the core reduction sequence described above, with bipolar flakes being significantly lighter than freehand flakes (Table 4).

In short, the whole core reduction/flake production process at Bai Ben can be described using the continuum 


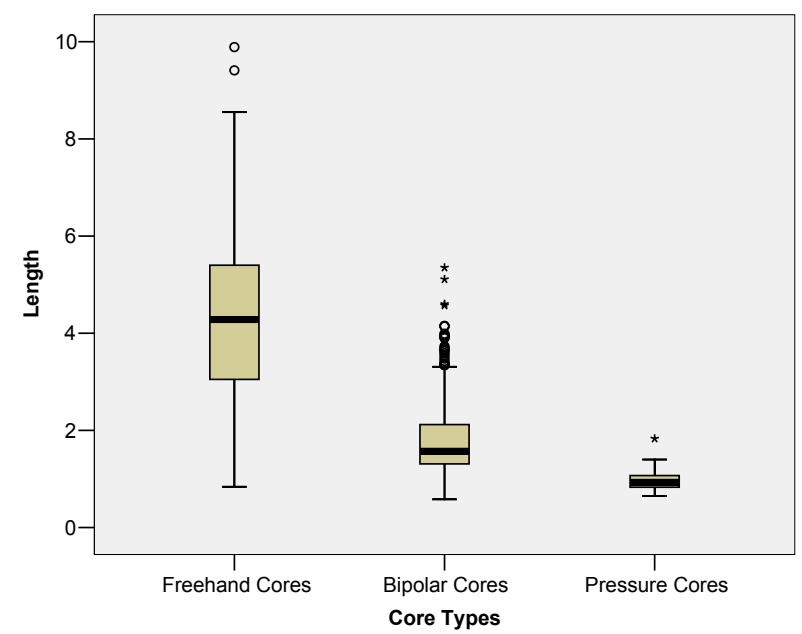

Figure 4: The overlapping values of length for freehand, bipolar, and pressure flaked cores at Bai Ben.

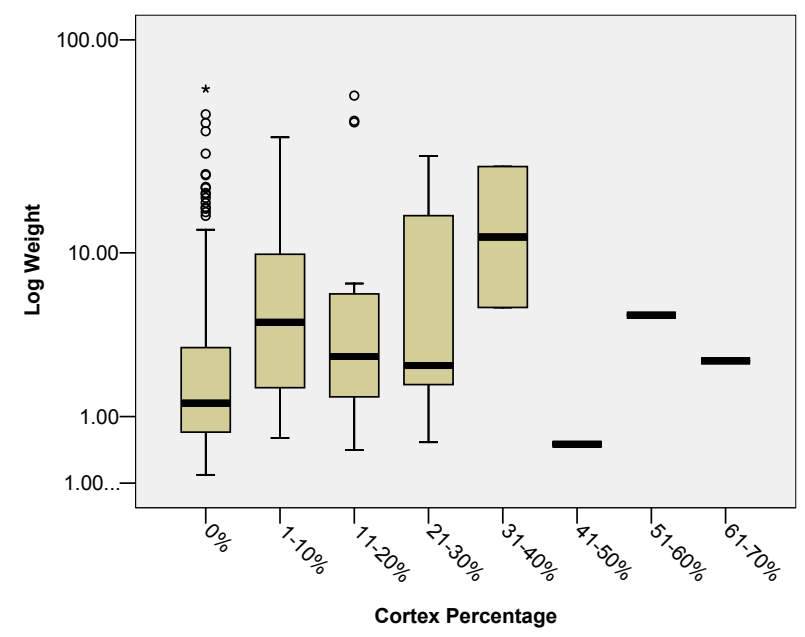

Figure 5: Boxplot of cortex percentage and mass for bipolar cores showing three small cores (the single lines at the right hand end of the graph) with 41-70\% cortex remaining.

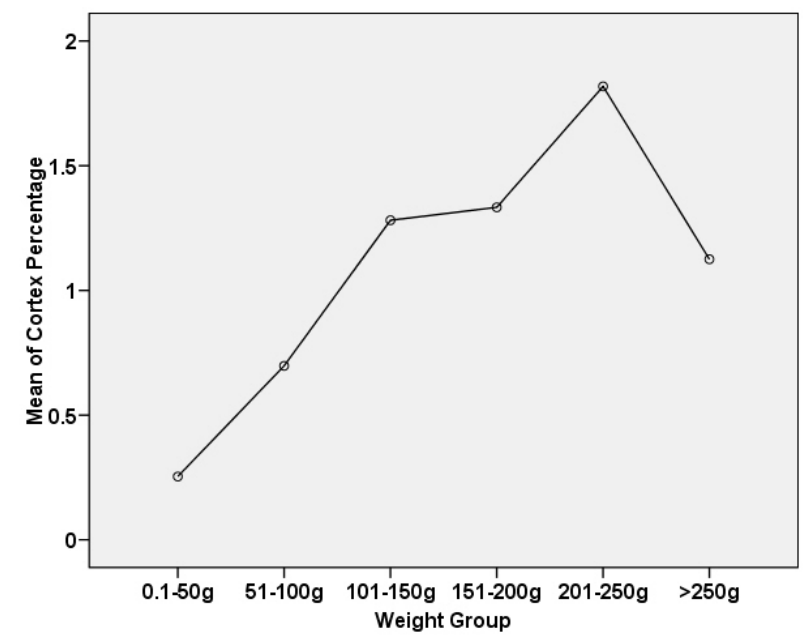

$6 a:(d f=5 ; F=17.940 ; p=.000)$

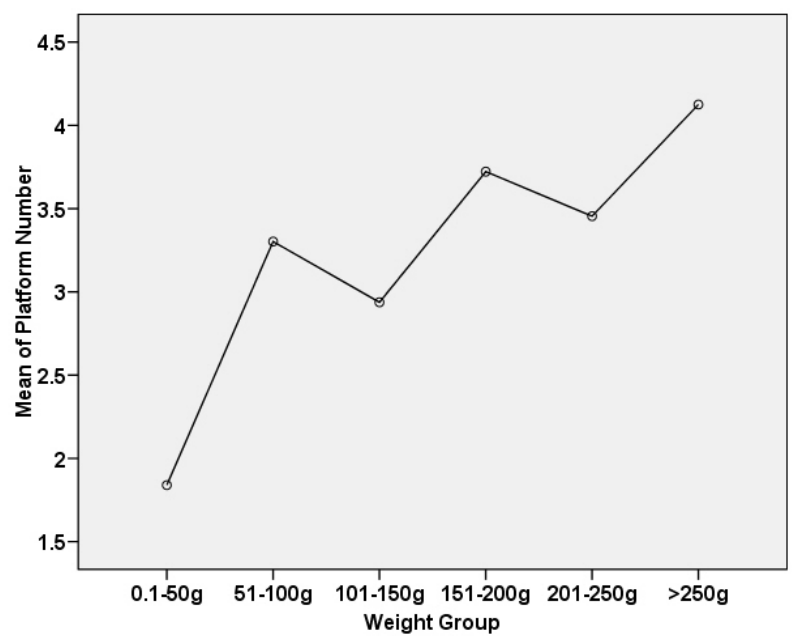

$6 b:(d f=5 ; F=61.753 ; p=.000)$

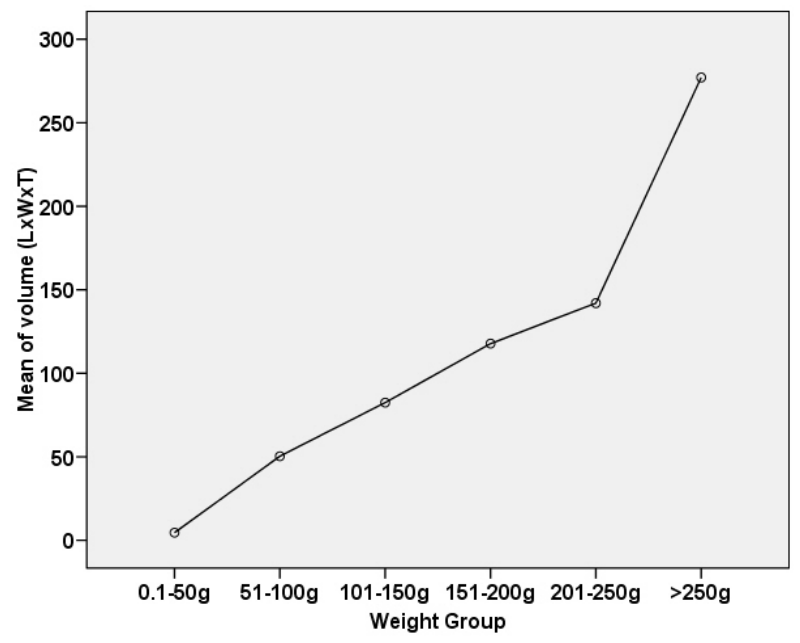

$6 c:(d f=5 ; F=940.666 ; p=.000)$

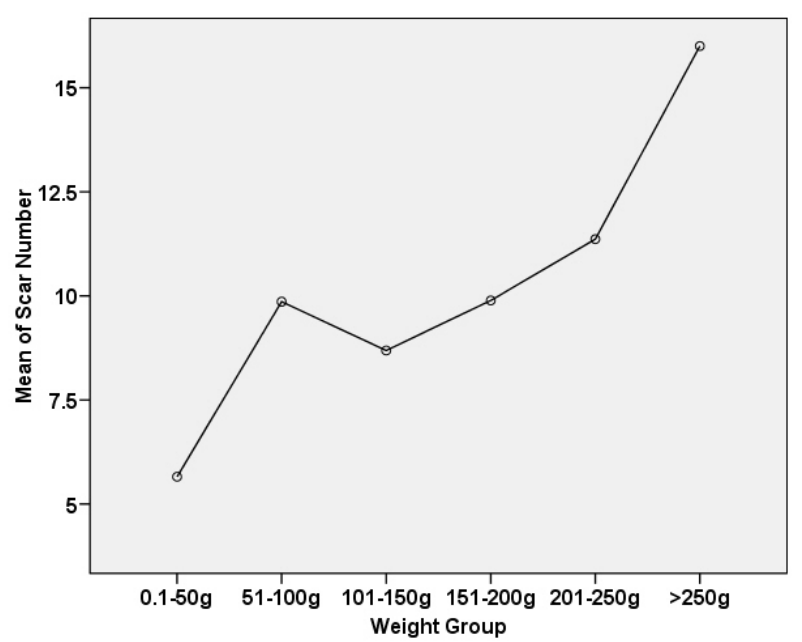

$6 d:(d f=5 ; F=48.216 ; p=.000)$

Figures 6a-d: Measures of reduction intensity by mass group for freehand cores. 


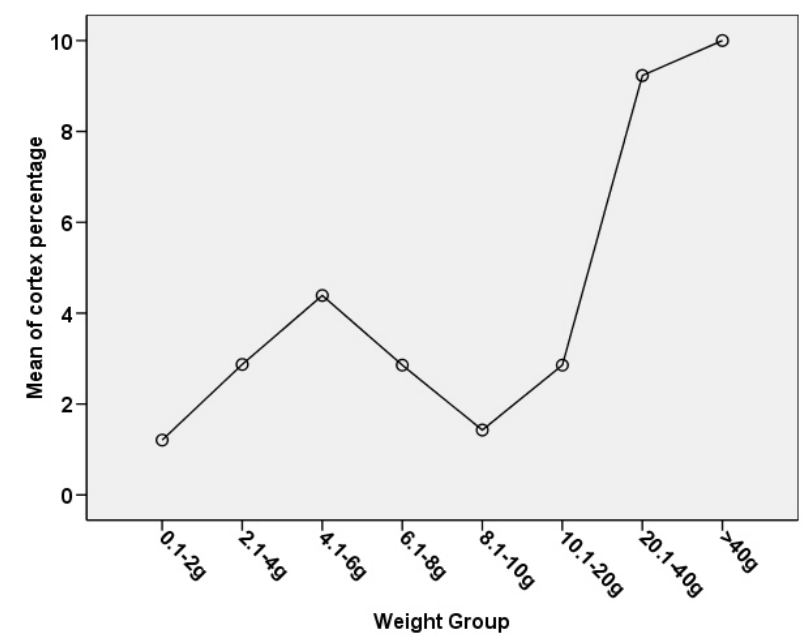

$7 a:(d f=7 ; F=4.123 ; p=<0.0005)$

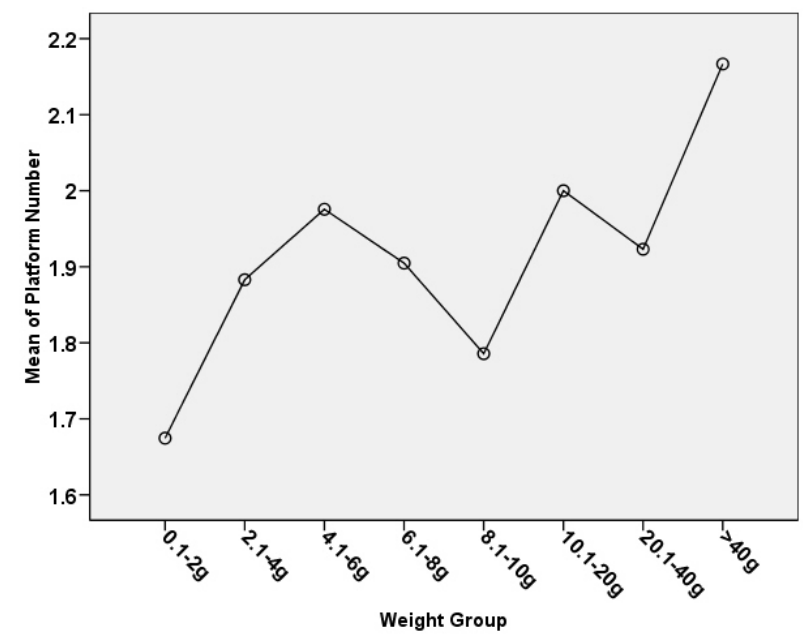

$7 b:(d f=7 ; F=3.129 ; p=.003)$

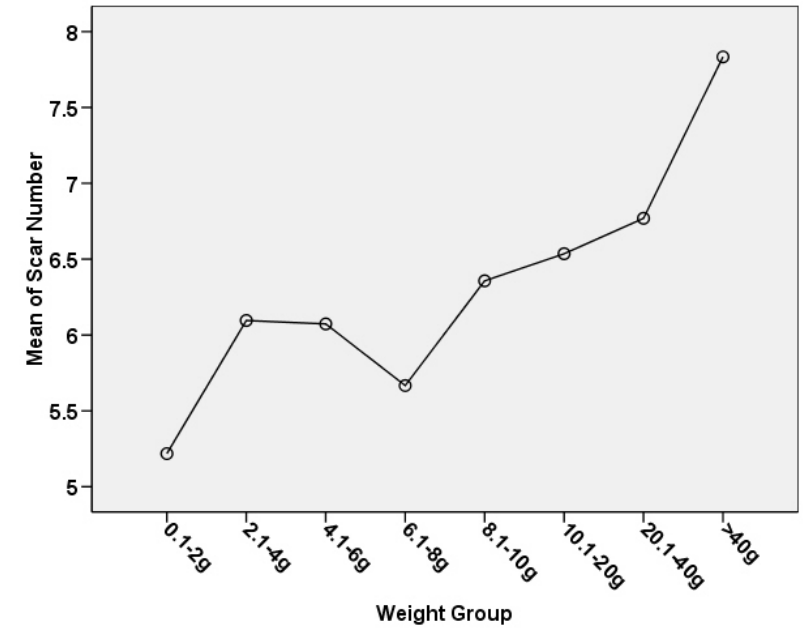

7c: $(d f=7 ; F=4.096 ; p=<0.0005)$

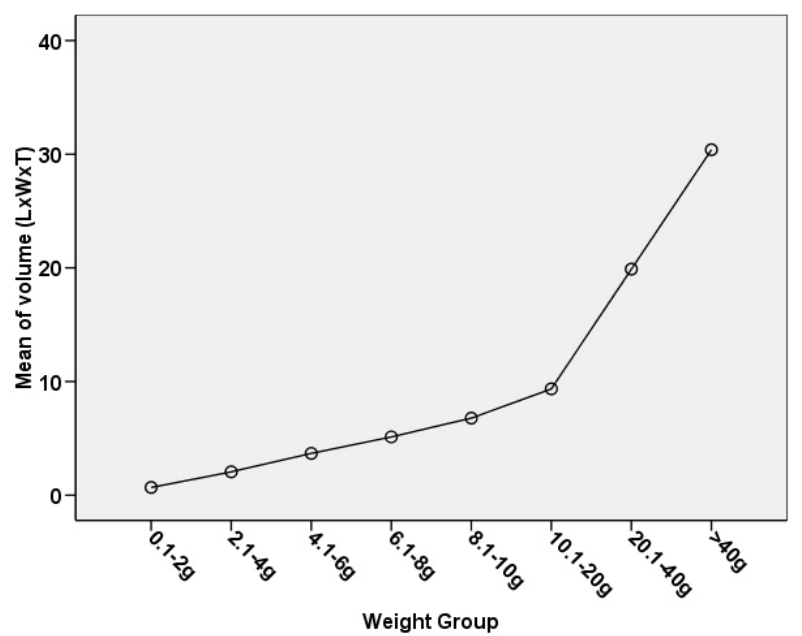

$7 d:(d f=7 ; F=790.666 ;<0.0005)$

Figures 7a-d: Measures of reduction intensity by mass group for bipolar cores.

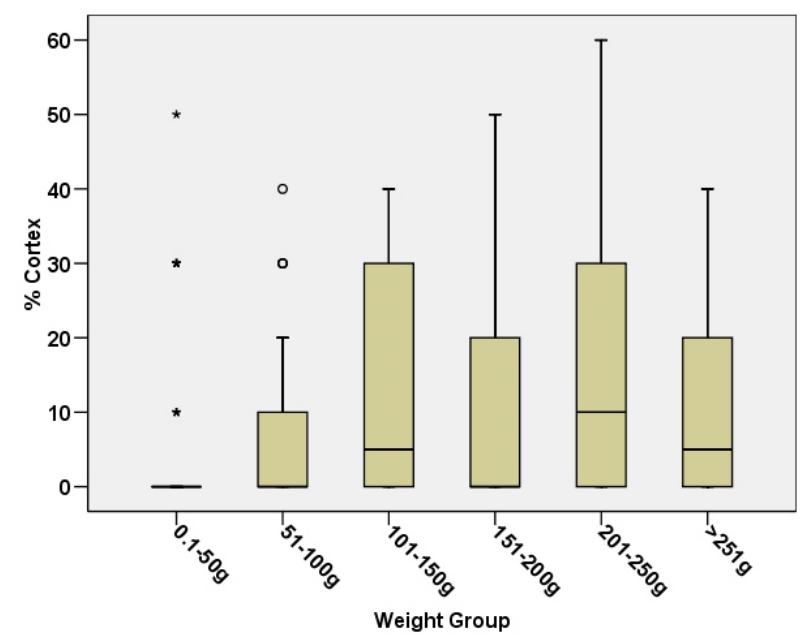

$8 a$

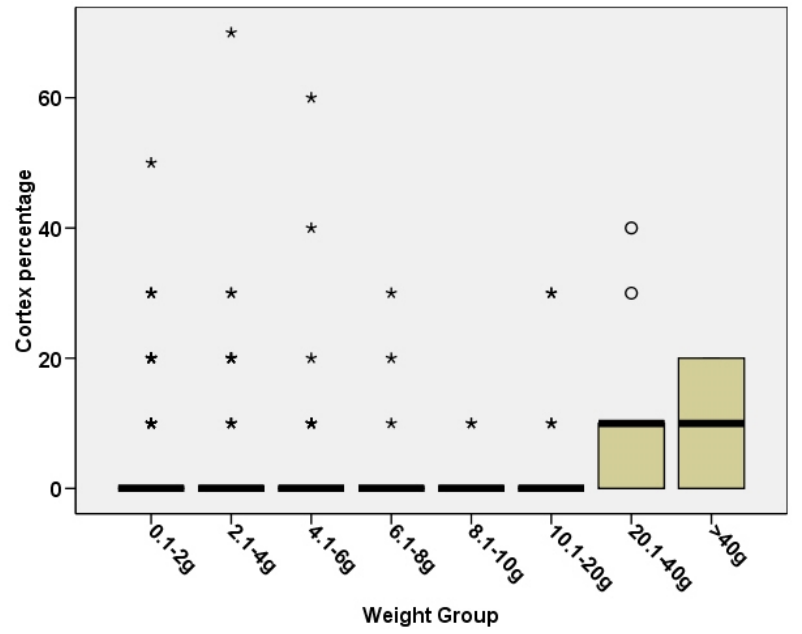

$8 b$

Figure 8: Boxplot of changing cortex percentage as a function of mass. A: freehand cores, B: bipolar cores. 


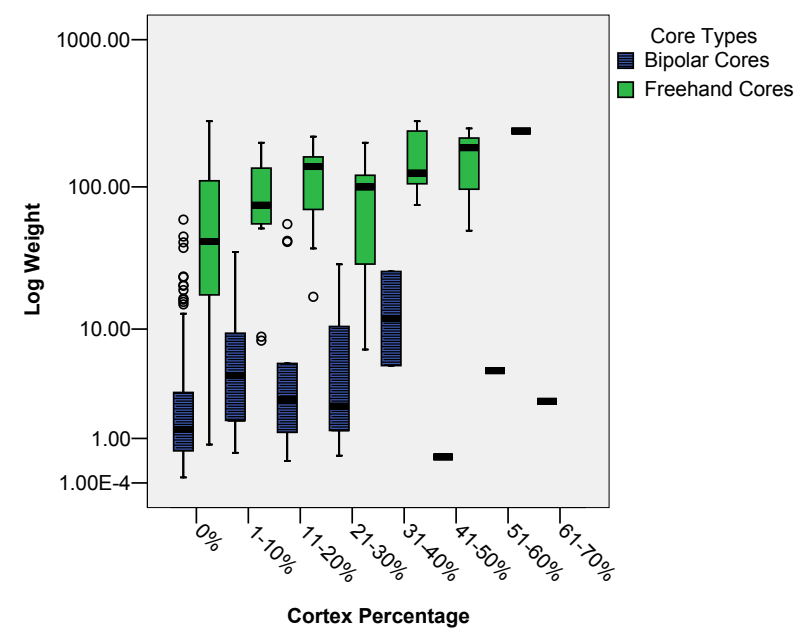

Figure 9: Log mass by cortex group for both freehand and bipolar cores.

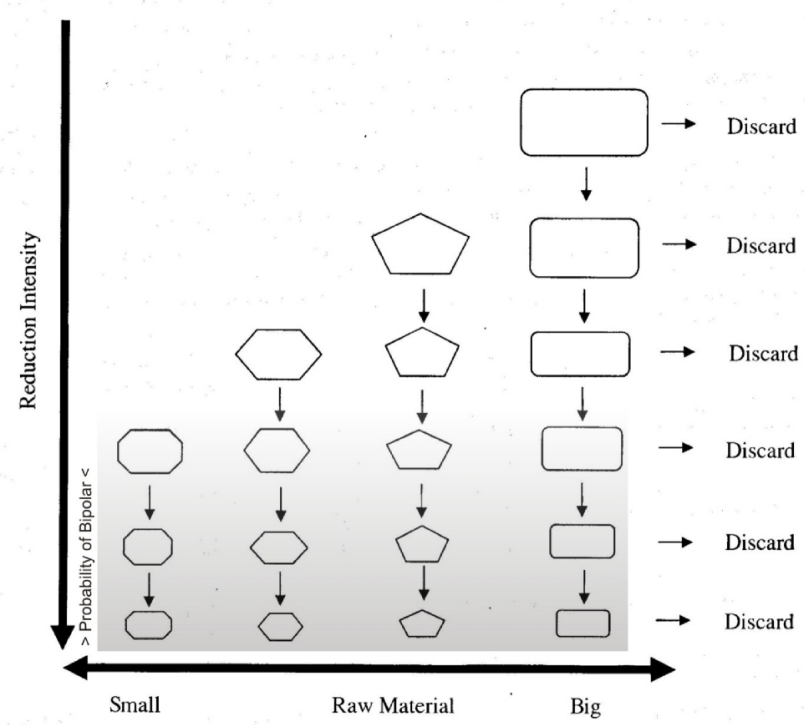

Figure 10: Proposed model of reduction sequences for core assemblage with various raw material sizes and discard behaviour.

Table 4: Comparison mean weight for chert bipolar and freehand flakes.

\begin{tabular}{llll}
\hline Crushed Termination & $\mathrm{N}$ & $\begin{array}{l}\text { Mean } \\
\text { mass } \\
(\mathrm{g})\end{array}$ & Std. Deviation \\
\hline Freehand & 45 & 4.89 & 11.24589 \\
Bipolar & 6 & .49 & 0.16923 \\
\hline
\end{tabular}

model presented in Figures 11. This model also includes discard behaviour in accordance with size and technology and indicates blank sources for drill production that encompasses freehand flakes, bipolar flakes, and small bipolar cores.

\section{Blank Selection}

Identifying criteria for selection for retouching into drill points involves comparing attributes of unretouched and lightly retouched flakes (most of which are not inconsistent with early stage drill points) to determine different morphological characteristics and hence the likely population of flakes selected for retouch (Clarkson 2007; Fish 1981; Dibble 1995:108). For this purpose we compared a range of dimensional, shape and dorsal scar characteristics as well as the proportion of freehand versus bipolar flakes for unretouched and lightly retouched flakes. Only complete chert flakes were included in the analysis, and only retouched flakes with less than four retouched segments were selected in order to ensure that flakes were not so heavily retouched as to obscure dorsal and dimensional characteristics. This selection process resulted in a population of 417 unretouched flakes and 29 retouched flakes.

\section{Size}

Figure 12 shows the results of size comparisons between unretouched and lightly retouched flakes. It is clear from these graphs that short, narrow flakes were preferentially selected for drill point manufacture from a pool of much larger flakes, with desirable lengths ranging from 6.5 to $17.3 \mathrm{~mm}$ and widths ranging from 2.6 to $6.8 \mathrm{~mm}$.

\section{Shape}

Comparison of shape indices for unretouched and lightly retouched flakes shown in the scatter plots in Figure 13 also indicate that flakes selected for drill point manufacture meet tight selection criteria. Early stage drill points are more or less parallel-sided with a mean elongation (length/width) of 2.5 versus 1.5 for unretouched flakes, a longitudinal cross section (length/thickness) of 4.4 versus 6.0 for unretouched flakes, and a transverse cross section ratio of 1.8 for retouched flakes, as opposed to 4.3 of unretouched flakes. Overall we can see that flakes chosen for drill point manufacture were elongate, parallel-sided, and thick relative to length and width.

\section{Dorsal Scar Characteristics}

Figure 14 compares the dorsal scar characteristics of unretouched and lightly retouched flakes. Flakes with dorsal surfaces obscured by retouch were recorded as undiagnostic. Comparison shows that the frequency of nondiagnostic surfaces and uni-directional flaking is high, whereas those of bi- directional and multi-directional scar orientations are very low, suggesting that while the impact of retouching on scar patterns is significant, unidirectional scar orientation were most commonly selected for retouching among both freehand and bipolar populations. The differences between uni-directional and other dorsal scar patterns are significant (Table 5).

\section{Proportion of Freehand vs Bipolar Flakes}

It is also possible to examine whether freehand or bipolar flakes were more commonly selected for drill point manu- 


\begin{tabular}{llllll}
\hline & Dorsal Scar Orientation & & & & Total \\
\hline & Non-Diagnostic & Uni-Directional & Bi-Directional & Multi-Directional & 432 \\
Freehand & 273 & 140 & 15 & 4 & $0.9 \%$ \\
$\%$ & $63.2 \%$ & $32.4 \%$ & $3.5 \%$ & 2 & $100 \%$ \\
Bipolar & 34 & 138 & 23 & $1.0 \%$ & 197 \\
$\%$ & $17.3 \%$ & $70.1 \%$ & $11.7 \%$ & 6 & $100 \%$ \\
Total & 307 & 278 & 38 & & 629 \\
$\left(x^{2}=116.954 ; p=.000\right)$ & & & & \\
\hline
\end{tabular}

Table 5: Frequencies of retouched flakes according to dorsal scar orientation and flake types.

Morphological sequences

Raw material

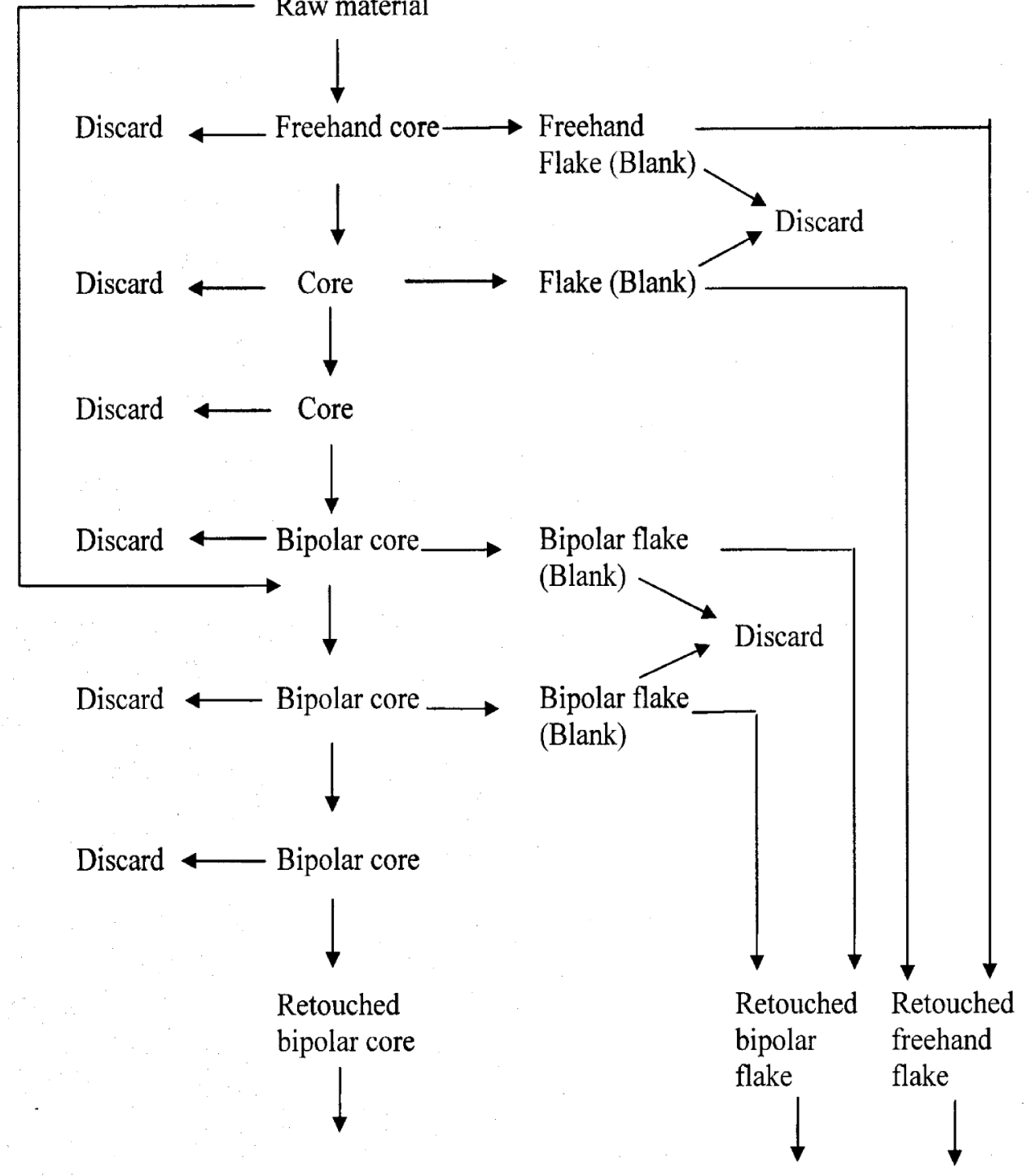

Size Technology

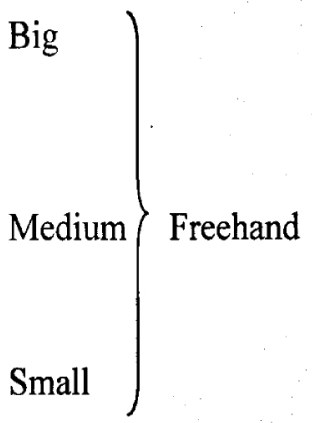

$\left.\begin{array}{l}\text { Big } \\ \text { Medium } \\ \text { Small }\end{array}\right\}$ Bipolar

Retouching

(Pressure

flaking)

Figure 11: Reduction continuum model of core transformation at Bai Ben based on size, technology, and discard behaviour. Blank sources for drill manufacture are also indicated 


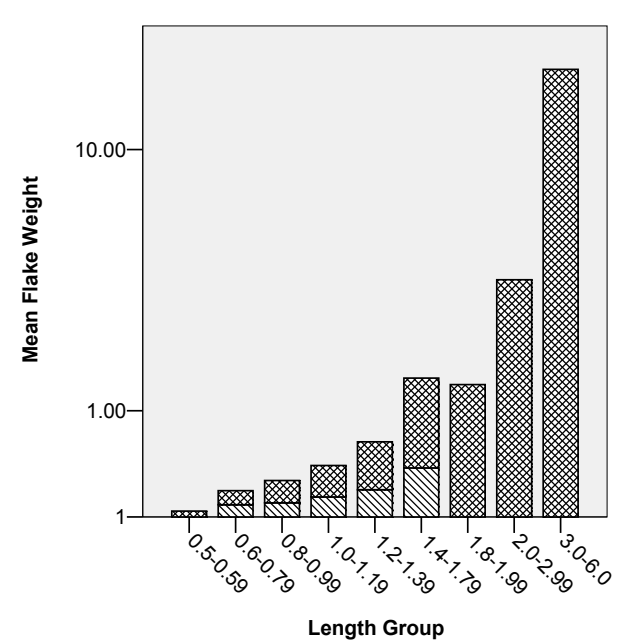

$12 a$

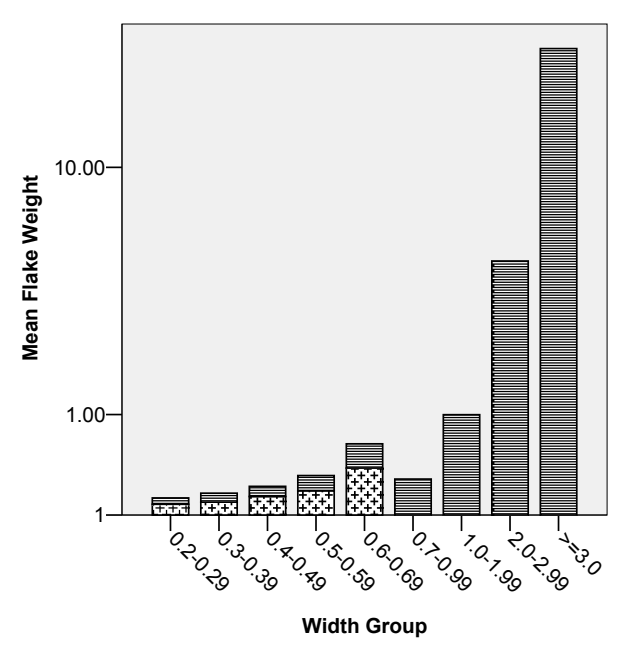

$12 b$

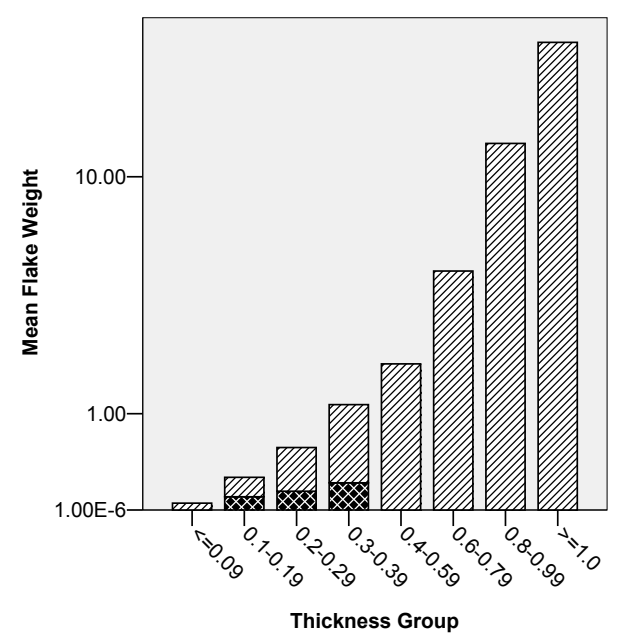

$12 c$

Flake Types
$\mathbb{Q}$ Retouched

Unretouched

Flake Types

Retouched

貝 Unretouched

Flake Types $\otimes$ Retouched

Unretouched

Figure 12: Mean comparisons of the distribution of size values for lightly retouched and unretouched flakes for length (A), width (B), and thickness (C).

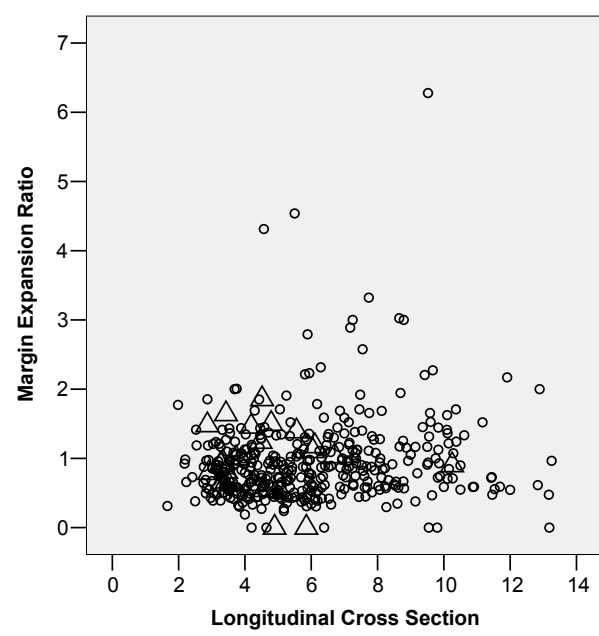

Flake Types $\triangle$ Retouched

$\bigcirc$ Unretouched

$13 a$

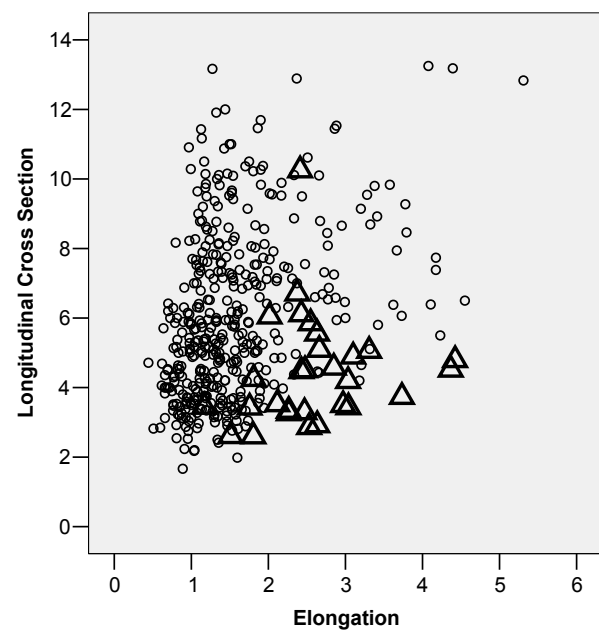

Flake Types $\triangle$ Retouched $\bigcirc$ Unretouched
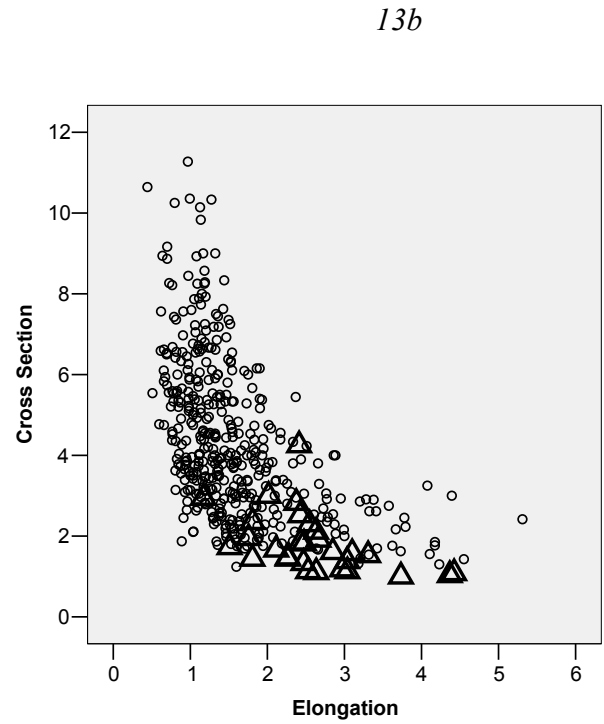

$13 c$ 


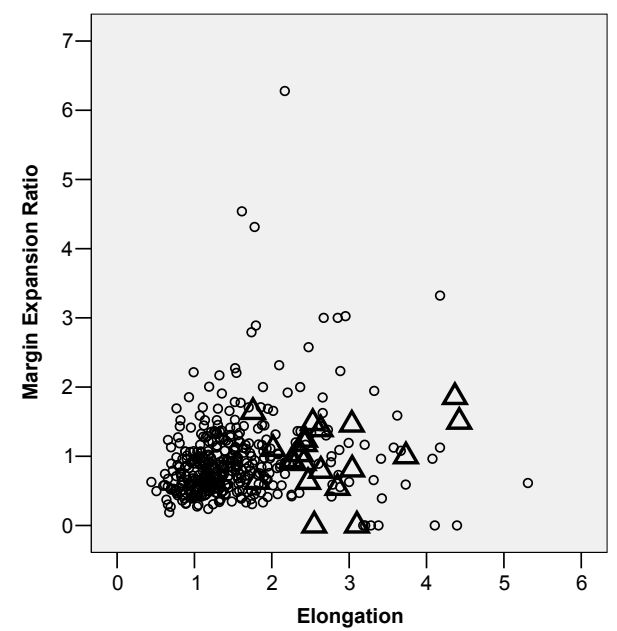

$13 d$

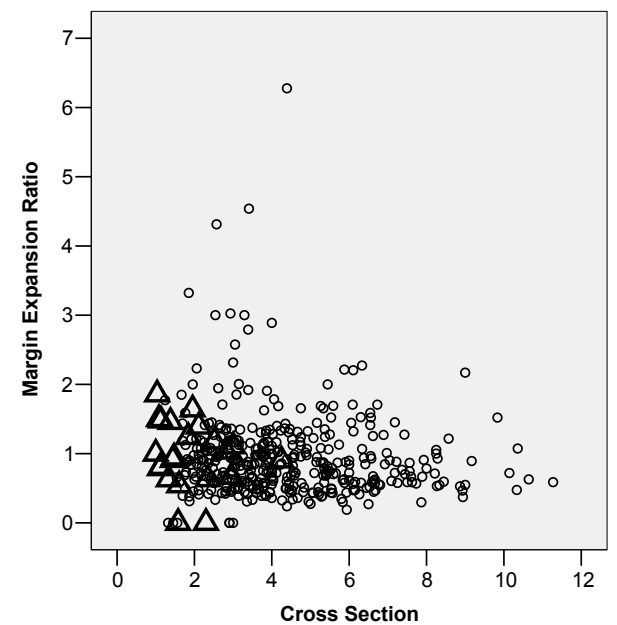

$13 e$

Figure 13: Variation in shape for lightly retouched flakes in comparison with unretouched flakes. A, Margin expansion ratio against longitudinal cross section; $B$, Longitudinal cross section plotted against elongation; $C$, Cross section plotted against elongation; D, Margin expansion ratio plotted against elongation; E, Marginal expansion ratio plotted against cross section.

facture. It can be seen that while around $55 \%$ of freehand flake are selected for retouch, about $72 \%$ of bipolar flakes are selected (Table 6). This therefore indicates that bipolar flakes were more commonly selected for drill point manufacture than freehand flakes.

Table 6: Frequencies of freehand and bipolar flakes selected from early stage drill point manufacture.

\begin{tabular}{llll}
\hline Flake Types & Retouched & Unretouched & Total \\
\hline Freehand & 432 & 341 & 773 \\
$\%$ & 55.89 & 54.11 & 100 \\
Bipolar & 197 & 76 & 273 \\
$\%$ & 72.16 & 27.84 & 100 \\
\hline
\end{tabular}

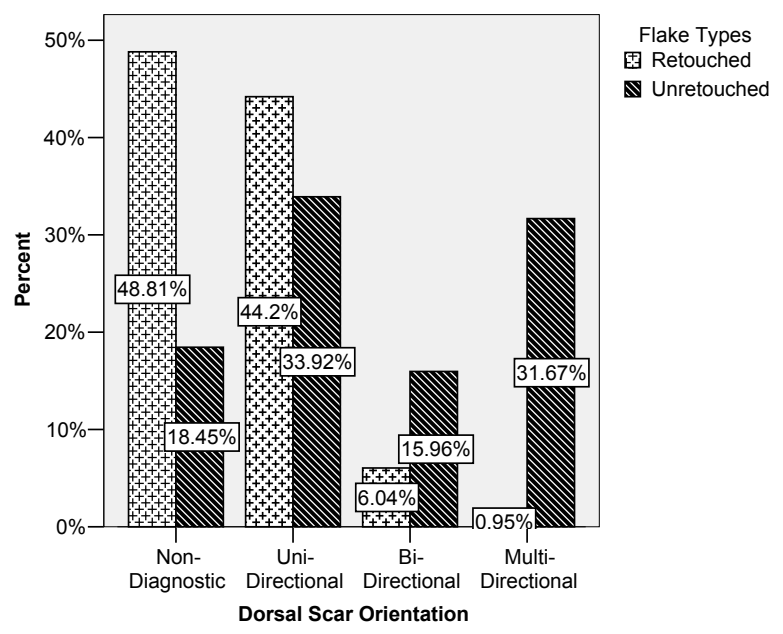

Figure 14: Frequencies of negative scar orientation for unretouched and retouched flakes

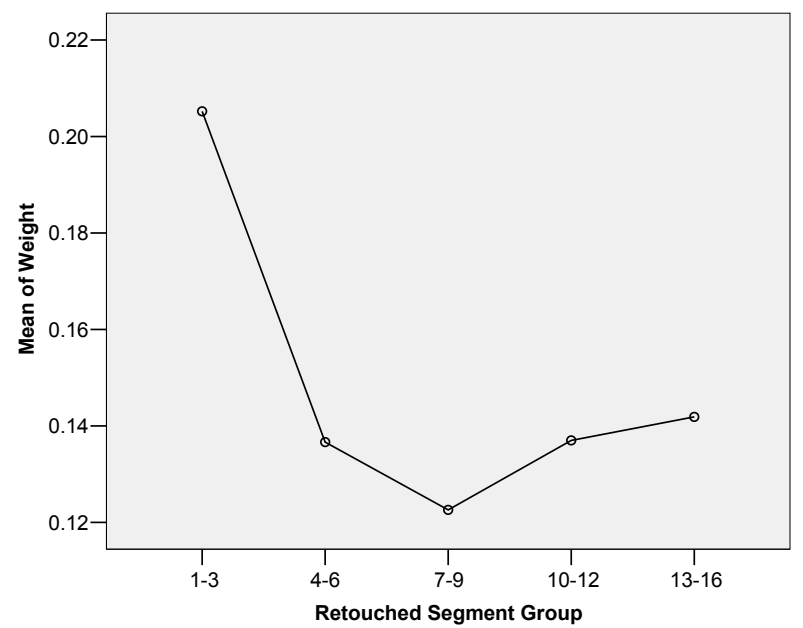

15a: $(d f=4 ; F=10.646 ; p=.000)$

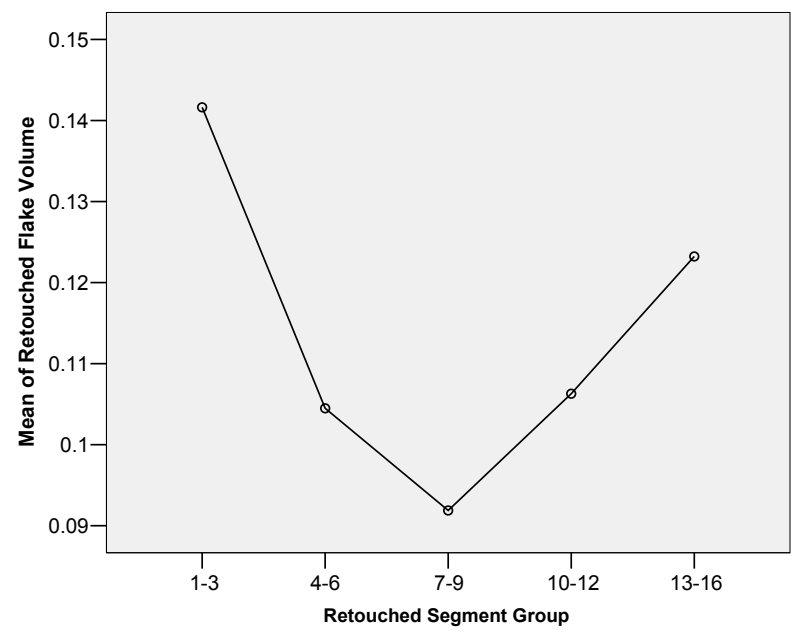

$15 b:(d f=4 ; F=8.320 ; p=.000)$ 


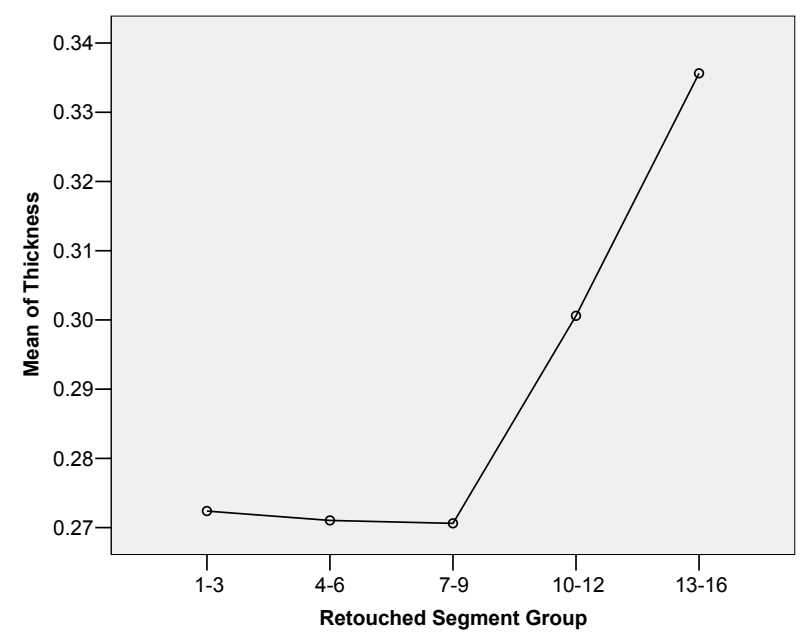

$15 c:(d f=4 ; F=7.999 ; p=.000)$

Figure 15: Mean plots of weight (A), retouched flake volume (B), and thickness (C) against retouched segment group.

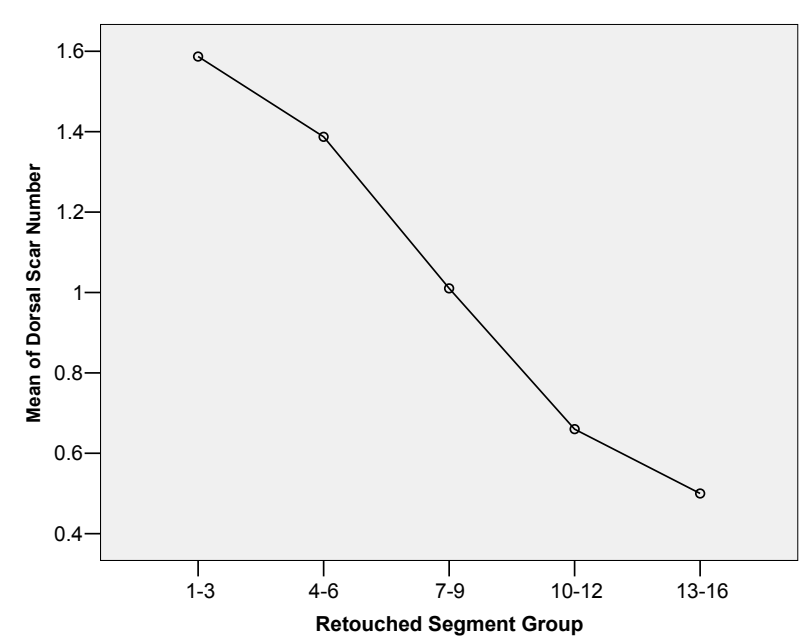

16a: $(\mathrm{df}=4 ; \mathrm{F}=12.228 ; \mathrm{p}=<0.0005)$

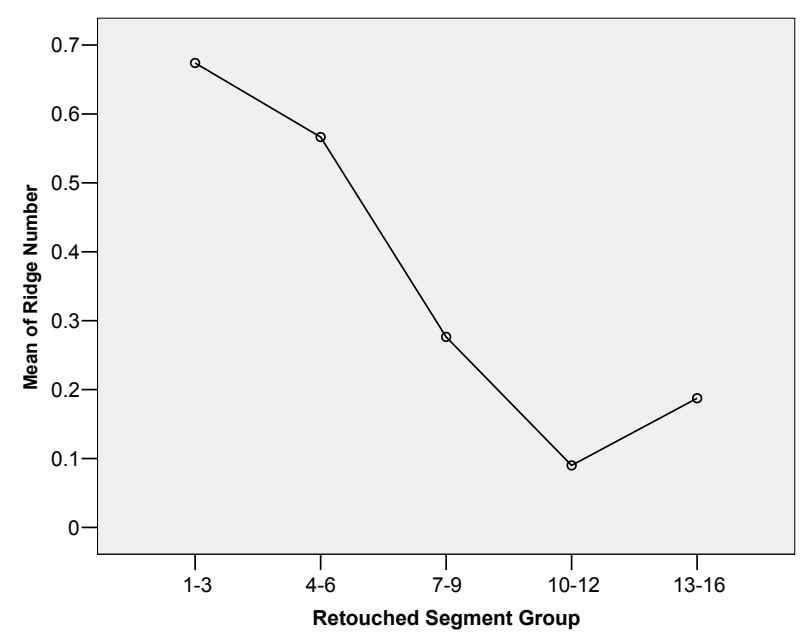

16b: $(d f=4 ; F=12.339 ; p=<.0005)$

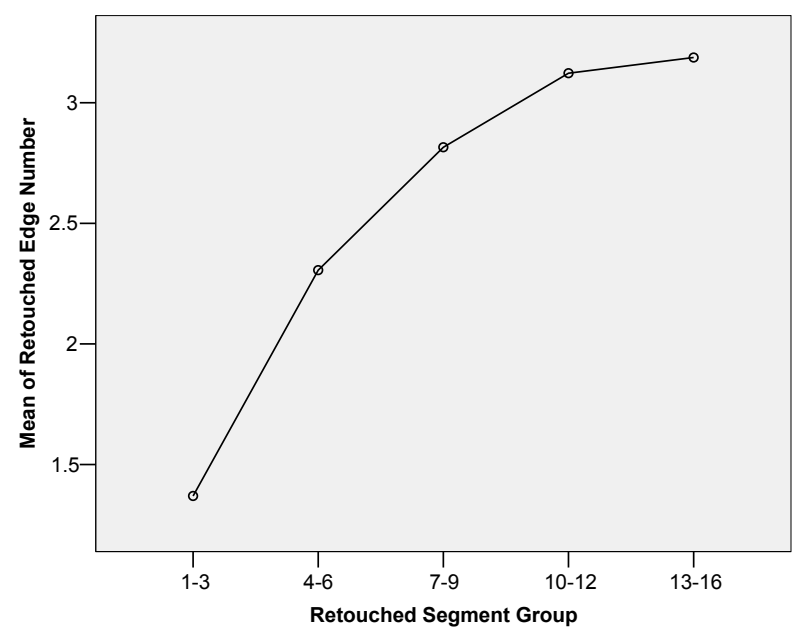

$16 c:(d f=4 ; F=82.919 ; p=<0.0005)$

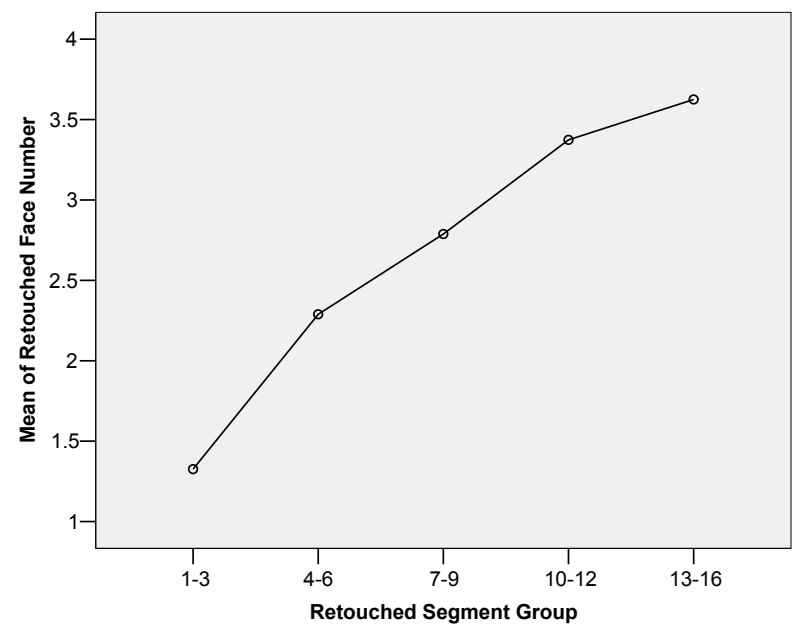

16d: $(d f=4 ; F=104.564 ; p=<0.0005)$

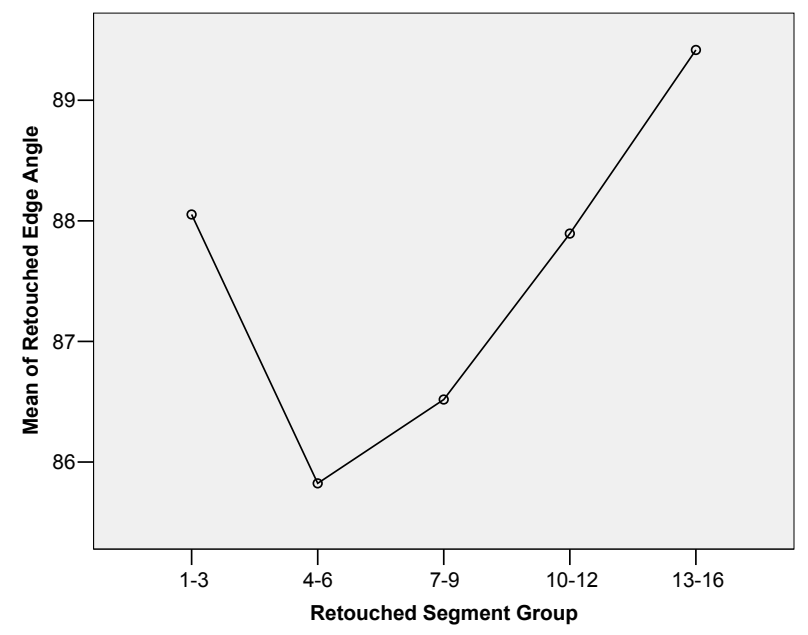

16e: $(d f=4 ; F=2.539 ; p=.039)$

Figure 16: Morphological changes as a function of increasing retouch segment groups, $A$, dorsal scar number; $B$, longitudinal ridge number; $C$, retouched edge number; $D$, retouched face number; E, retouched edge angle. 
Table 7: Mass comparison between freehand and bipolar retouched flake assemblage.

\begin{tabular}{llllllll}
\hline & & $\mathrm{N}$ & Mean & Std. Deviation & t-value & $\mathrm{df}$ & $\mathrm{p}$ \\
\hline Flake Weight $(\mathrm{g})$ & Freehand & 432 & 0.13 & 0.08209 & -1.434 & 627 & 0.152 \\
& Bipolar & 197 & 0.14 & 0.08446 & & & \\
\hline
\end{tabular}

Bipolar reduction methods often generate elongate flakes with thick cross section, and uni- and bi-directional scar orientations, and bipolar flakes were therefore more commonly selected for drill point manufacture, even though bipolar flakes make up a smaller proportion of the overall assemblage. There is no statistical difference in the mass of freehand and bipolar retouched flakes, suggesting that flakes of equal size could be and were selected from both populations of flakes (Table 7).

In sum, the comparative analyses between lightly retouched and unretouched flake populations revealed that tight size and shape criteria were applied in drill blank selection and that selection rested on a number of criteria relating to flake size, shape, and dorsal morphology. It was found that flakes which are elongate and thicker relative to width with unidirectional dorsal flake scar orientations were preferred to flakes that are elongate and thin for retouching into drills. Flakes that possess these characteristics were more often produced by bipolar than freehand percussion and these were chosen preferentially despite being less common at the site.

\section{Drill Production}

In this section we explore the reduction sequence for retouched drill points in terms of changes to flake dimensions, shape and retouch location. Given the nature of lithic reductive technology, it is hypothesized that if all drills in the assemblage represent points or stages along a single reduction trajectory, more reduced drills would be smaller than less worked ones, given similar sized blanks to begin with. It can be seen from Figure 15 that overall mean mass and volume of retouched flakes reduces dramatically in the early part of the reduction sequence as new segments are retouched. However, it can also been seen from this figure that mean mass and volume increase again as more segments are retouched. Thickness on the other hand increases steadily as more segments are retouched. We can therefore surmise that thin drill points must steadily drop out of the population as drills are progressively retouched, with only the thicker drill points continuing to later stages of reduction.

More heavily retouched drills should exhibit fewer dorsal scars, longitudinal ridges, a greater number of retouched faces and edges, and increasing final retouched edge angle as reduction progresses. Indeed, such alterations to flake morphology are evident as the number of retouched segments increases, as seen in Figure 16, and all correlations between variables are highly significant. In other words, increasing retouch intensity resulted in progressively erasing flake scars and ridges that previous- ly existed on the dorsal surfaces of specimens, and at the same time added retouched scars on multiple faces and edges.

\section{Discard Criteria}

The changes noted above in flake thickness as retouch progresses indicate that drills of different morphologies were discarded at different stages of reduction. To explore which criteria might have driven the discard of drills, it is necessary to first find out at what degree of retouch drills were most frequently discarded. Based on this result, it will be possible to explore whether certain variables such as high final retouched edge angles might have been important reasons for discard.

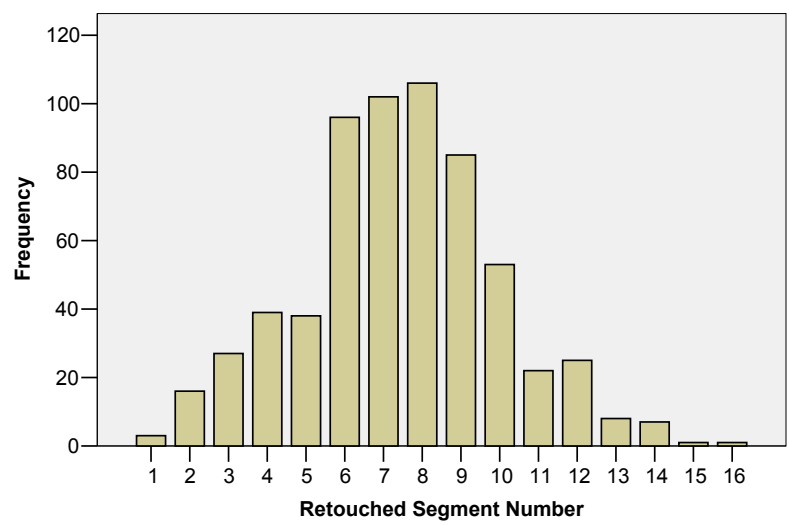

Figure 17: Frequency of retouched segment number.

Table 8: Descriptive statistics for retouched segment number

\begin{tabular}{|c|c|}
\hline Valid/Missing & $629 / 0$ \\
\hline Mean & 7.42 \\
\hline Std. Deviation & 2.556 \\
\hline Skewness & 0.098 \\
\hline Std. Error of Skewness & 0.097 \\
\hline Range & 15 \\
\hline Minimum & 1 \\
\hline Maximum & 16 \\
\hline
\end{tabular}

Table 8 and Figure 17 provide the central tendency and the distribution of retouched segment number for 629 drill points. We see that the retouched segment population is normally distributed and only slightly skewed, with the mean falling between 7 and 8 retouched segments. This means that $68 \%$ of the drill assemblage falls between 5 and 10 retouched segments. In other words, the majority 
of drills were discarded at only moderate stages of reduction. This corresponds to the discard of thin blanks that were not taken on to higher levels of reduction. Drill points that were discarded at high levels of reduction were only those with thick cross-sections capable of withstanding high levels of retouch without breaking.

Retouched edge angle appears to be another important criterion in drill-point discard. The mean edge angle of drill points at discard is $86.7 \pm 6.3$ degrees, meaning that $68 \%$ of all drill points have very steep retouched edge angles that lie within about 80 and 93 degrees (Table 9, Figure 18).

Table 9: Descriptive statistics for retouched edge angle for all cases.

\begin{tabular}{ll}
\hline $\mathrm{N} \quad$ Valid/Missing & $532 / 97$ \\
\hline Mean & 86.73 \\
Std. Deviation & 6.313 \\
Skewness & -1.111 \\
Std. Error of Skewness & 0.106 \\
Range & 52 \\
Minimum & 58 \\
Maximum & 110
\end{tabular}
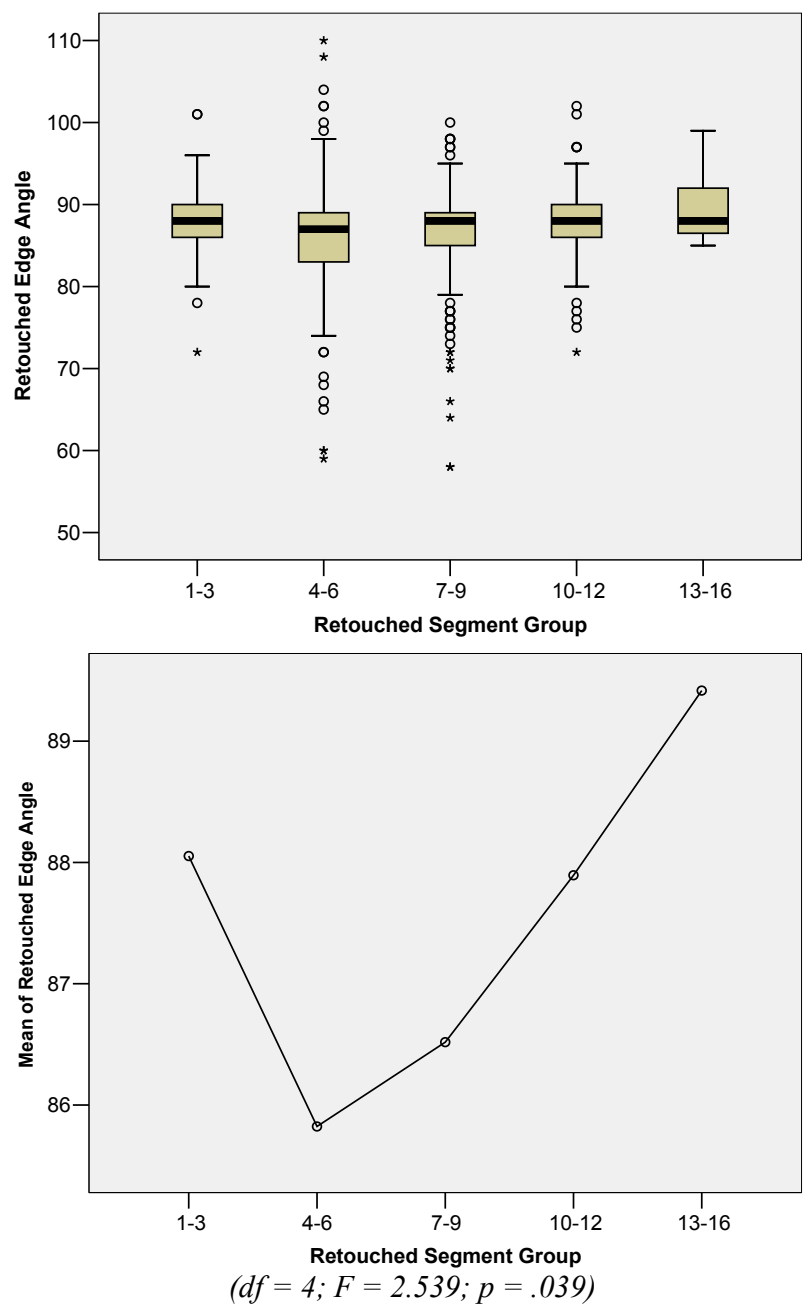

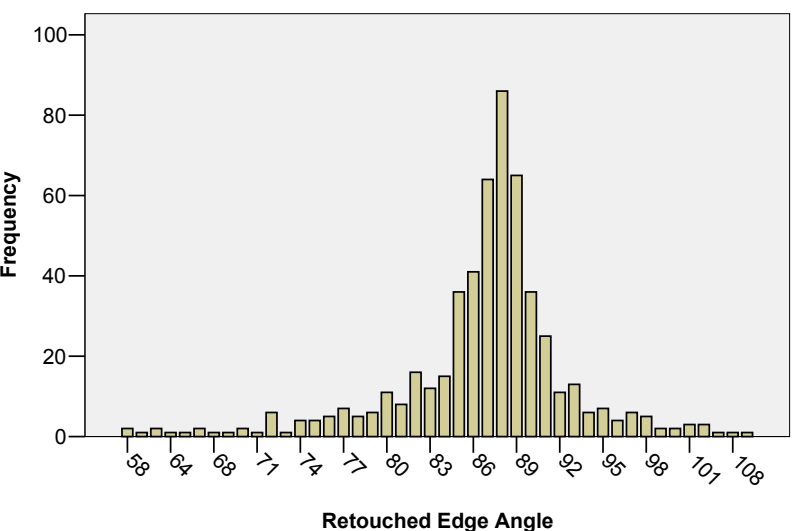

Figure 18: Boxplot and mean plot of retouched edge angle along the retouched segment scale, and histograms of retouched edge angles for all cases.

This high angle criterion for discard might also explain why a certain number of specimens were discarded at early stages of reduction (i.e., 1-3 retouched segments), having already attained these high edge angles, irrespective of the remaining mass of each specimen and hence their remaining 'reduction potential' (Hiscock, 2006; Kuhn, 1990). Why steep edge angles should result in discard is unclear at present, but presumably has to do with drill-point function and most likely the inability to further resharpen points once they obtain obtuse edge angles.

The proposed reduction model for drills is depicted in Figure 19.

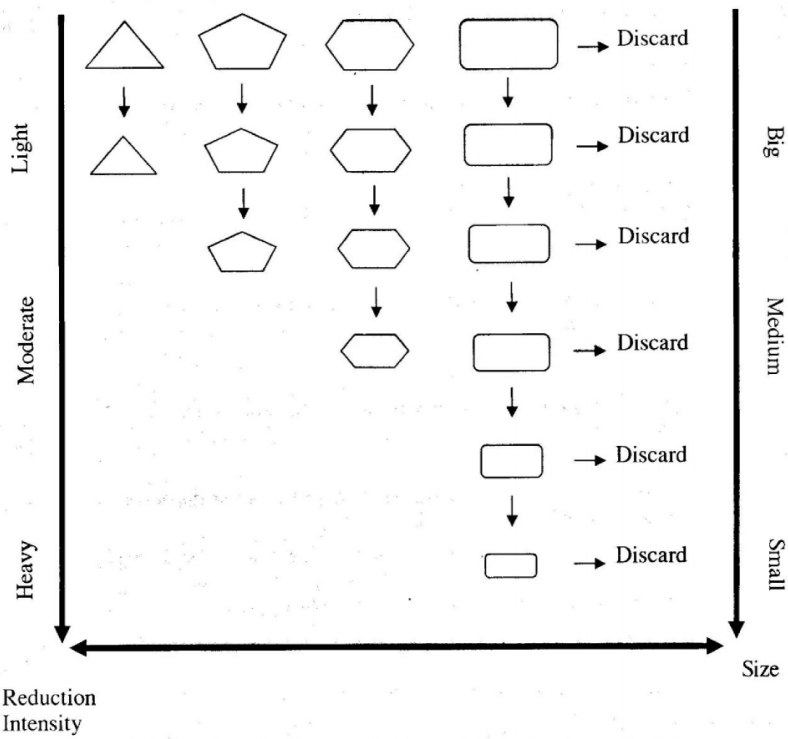

Figure 19: Reduction model for drill production at Bai Ben.

\section{SUMMARY OF TECHNOLOGICAL BEHAVIOUR AT BAI BEN}

In order to manufacture drill points, Bai Ben residents went to obtain stone raw materials from nearby areas and brought them back to the site. The raw material sources, which are predominantly chert, are readily available in the local region such as in the streambed or on the land surface, and procurement was therefore not very difficult. 
The task could have been undertaken as an embedded activity within existing subsistence schedules or as direct procurement involving specialised trips to stone sources. Chert was apparently selected on the basis of its quality rather than size or form. Chert nodule size and form are hugely variable. The nodules were subsequently knapped to produce usable flakes by employing two reduction strategies, freehand and bipolar percussion, which existed both as a technological continuum or as alternatives for working different sized nodules. It is clear that raw material size affected the choice of technology. This factor was also found to influence the length of reduction sequences. That is, smaller raw materials would result in shorter sequences of reduction with a greater likelihood of bipolar reduction starting early in the reduction sequence, whereas larger nodules underwent longer reduction sequences with a greater proportion of the sequence being freehand percussion. The fact that many cores were discarded without switching to bipolar flaking regardless of remaining mass presumably reflects raw material availability. There was clearly no need to economize on raw material use when fresh nodules were abundant and available nearby.

Bai Ben inhabitants then selected suitable flake blanks to make drill points, mostly from the larger pool of unretouched flakes as well as from the small bipolar cores themselves. The chosen blanks are quite similar in size, usually elongate, thick relative to width, and uni- and/or bi-directional in scar orientation.

The blanks were retouched primarily to reduce the width of specimens using pressure flaking, beginning with one or two edges, and then expanding to three and/or four edges if need be. The size of blanks appears to have largely determined the amount of retouch applied. That is, bigger blanks were usually more heavily retouched than smaller ones. Artefact width was gradually reduced as a result of increasing retouch intensity and approached virtually equal dimensions to thickness at the completion of retouch, which in turn made drills symmetrical in crosssection, more resilient to breakage and probably better functioning as drill bits. The drills were normally discarded at moderate retouch intensity, and after having attained thick cross-sections, elongate shape, parallel margins, and steep final retouched edge angle. Most of the discarded drills had attained these characteristics and can likely be considered finished and desired products.

\section{CONCLUSION}

This study of reduction behaviour at the Neolithic drill point factory of Bai Ben is the first of its kind in Vietnamese prehistory. We have successfully documented the process of procurement, core reduction, blank selection and drill point reduction and discard, building understanding of the fundamental aspects of technological organisation at the site. The study demonstrates a variable reduction process aimed at producing highly standardized products presumably intended for a highly specialised purpose of drilling shell beads. Further work is required to better understand the function of Bai Ben drill points and in particular the relationship between discard criteria and drill point functionality and further potential for resharpening.

\section{ACKNOWLEDGEMENT}

The paper is a summary of the author's $\mathrm{PhD}$ thesis completed at the University of Queensland under the principle supervision of Dr. Christopher Clarkson and three other advisors, namely Associate Professor Jay Hall, Associate Professor Ian Lilley, and Dr. Leonn Satterthwait. On this occasion, I would like to thank my advisory team once again.

\section{REFERENCES}

Allen, J., Holdaway, S., \& Fullagar, R. (1997). Identifying Specialisation, Production and Exchange in the Archaeological Record: the Case of Shell Bead Manufacture on Motupore Island, Papua. Archaeology in Oceania 32: 13-38.

Amick, D. S. (1994). Technological Organization and the Structure of Inference in Lithich Analysis: An Examination of Folsom Hunting Behavior in the American Southwest. In P. J. Carr (Ed.), American Prehistoric Chipped Stone Tool Technologies (pp. 9-34). Ann Arbor, Michigan: International Monographs in Prehistory.

Andrefsky, W. (1994). Raw-Material Availability and the Organization of Technology. American Antiquity 59: 21-34.

Arnold, J. E. (1987). Technology and Economy: Microblade Core Production from the Channel Islands. In J. K. Johnson \& C. A. Morrow (Eds.), The Organization of Core Technology (pp. 207-237). Boulder and London: Westview Press.

Bamforth, D. B. (1985). The Technological Organization of Paleo-Indian Small-Group Bison Hunting on the LLano Estacado. Plains Anthropologist 30: 243-258.

Bamforth, D. B. (1991). Technological Organization and Hunter-Gatherer Land Use: A California Example. American Antiquity 56: 216-234.

Baumler, M. F. (1988). Core Reduction, Flake Production, and the Middle Paleolithic Industry of Zobiste (Yugoslavia). In H. Dibble, and Montet-White, A. (Ed.), Upper Pleistocene Prehistory of Western Eurasia (pp. 255-274). Philadelphia, Pennsylvania: University Museum Press.

Binford, L. R. (1979). Organizational and Formation Processes: Looking at Curated Technologies. Journal of Anthropological Research 35: 255-273.

Binford, L. R. (1980). Willow Smoke and Dogs' Tails: HunterGatherer Settlement Systems and Archaeological Site Formation. American Antiquity 45: 4-20.

Bleed, P. (2001). Trees or Chains, Links or Branches: Conceptual Alternatives for Consideration of Stone Tool Production and Other Sequential Activities. Journal of Archaeological Method and Theory 8: 101-127.

Buchanan, B. (2002). Folsom lithic procurement, tool use, and replacement at the Lake Theo site, Texas. Plains Anthropologist 47: 121-146.

Calley, S., \& Grace, R. (1988). Technology and function of Micro-borers from Kumartepe (Turkey). In S. Beyries (Ed.), Industries lithiques: tracéologie et technologie (Vol. 411 (1), pp. 69-81). Oxford: B.A.R. International Series. 
Carr, P. J., \& Bradbury, A. P. (2001). Flake Debris Analysis, Levels of Production, and the Organization of Technology. In W. Andrefsky (Ed.), Lithic Debitage: Context, Form, Meaning (pp. 126-146). Salt Lake City, Utah: The University of Utah Press.

Church, T. (1994). Lithic Resource Studies: A Sourcebook for Archaeologists: Special Publication \#3, Lithic Technology. Department of Anthropology, University of Tulsa.

Clarkson, C. (2002a). Holocene Scraper Reduction, Technological Organization and Land Use at Ingaladdi Rockshelter, Northern Australia. Archaeology in Oceania 37: 79-86.

Clarkson, C. (2002b). An Index of Invasiveness for the Measurement of Unifacial and Bifacial Retouch: A Theoretical, Experimental and Archaeological Verification. Journal of Archaeological Science 29: 65-75.

Clarkson, C. (2004). Technological Provisioning and Assemblage Variation in the Eastern Victoria River Region, Northern Australia: A Darwinian Approach. PhD Thesis. Australian National University.

Dibble, H. L. (1995). Biache Saint-Vaast, Level IIa: A Comparison of Analytical Approaches. In H. Dibble \& O. BarYosef (Eds.), The Definition and Interpretation of Levallois Variability (Vol. Monograph in World Archaeology Number 23, pp. 93-116). Madison, Wisconsin: Prehistory Press.

Dong, N. T. (2000). Các di vật đá: hạch đá, mảnh tước, phác vật mũi khoan và mũi khoan ở địa điểm Bãi Bến (Stone Artefacts: Cores, Flakes, Unfinished Drills and Drills at Bai Ben Site). In Báo Cáo Khai Quật Di Chỉ Bãi Bến Tháng 12 Năm 1999 (Report of Excavation at Bai Ben Site in December 1999) (pp. 15-23). Hà Nội: Viện Khảo cổ học (Institute of Archaeology).

Dong, N. T. (2001). Mũi khoan ở di chỉ Bãi Bến (Drills at Bai Ben Site). In Nhũng phát hiện mới về khảo cổ học năm 2000 (New Archaeological Discoveries in 2000) (pp. 124128). Hà Nội: Nhà xuất bản Khoa Học Xã Hội (Publishing House of Social Sciences).

Dong, N. T. (2006). Cắt ngang di chỉ Bãi Bến bằng mô hình Biến Đổi Giảm Dần (Transecting the Bai Ben Site Using the Reduction Model). Tạp chi Khảo cổ học (Journal of Archaeology) 3: 64-81.

Dong, N. T. (2007). A Technological Analysis at a Neolithic Lithic Workshop at Bai Ben, Vietnam. PhD Thesis. The University of Queensland, Brisbane.

Dong, N. T. (2008a). Có thực "mũi khoan" Bãi B ến là những mũi khoan? (Are the Bai Ben "Drill-Points" Real Ones?). In Nhũng phát hiện mói về khảo cổ học năm 2007 (New Archaeological Discoveries in 2007) (pp. 96-99). Hà Nội: Nhà xuất bản Từ điển Bách Khoa (The Publishing House of Encyclopaedic Dictionary).

Dong, N. T. (2008b). Người Bãi Bến kiếm đá ở đâu để sản xuất mũi khoan? (Where Did the Bai Ben People Procure Lithic Raw Material to Produce Drill Points?). In Nhũng phát hiện mói về khảo cổ học năm 2007 (New Archaeological Discoveries in 2007) (pp. 92-94). Hà Nội: Nhà xuất bản Từ điển Bách Khoa (The Publishing House of Encyclopaedic Dictionary).

Dong, N. T. (2008c). Các hình thức kỹ thuật ở Bãi Bến (The Percussion Techniques Employed at Bai Ben). In Nhũng phát hiện mói về khảo cổ học năm 2007 (New Archaeological Discoveries in 2007) (pp. 95-96). Hà Nội: Nhà xuất bản Từ điển Bách Khoa (The Publishing House of Encyclopaedic Dictionary).
Dong, N. T. (2008d). Cắt ngang di chỉ Bãi Bến - Mô hình và kiểm nghiệm mô hình (Transecting the Site of Bai Ben Model and Testing Model). Tạp chí Khảo cổ học (Journal of Archaeology) 2: 72-86.

Dong, N. T., Doi, N. G., \& Dung, N. K. (2000). Hach đá ở địa điểm Bãi Bến (Cát Bà-Hải Phòng) (Cores at Bai Ben Site (Cat Ba-Hai Phong)). In Nhũng phát hiện mói về khảo cồ hoc năm 1999 (New Archaeological Discoveries in 1999) (pp. 165-166). Hà Nội: Nhà xuất bản Khoa học Xã hội (Publishing House of Social Sciences).

Dung, N. K. (1996). Cong Xuong Va Ky Thuat Che Tac Do Trang Suc Thoi Dai Dong Thau Viet Nam (Workshops and Ornament Making Techniques in Bronze Age of Vietnam). Hanoi: Social Sciences Publishing House.

Dung, N. K., Buong, N. D., Phuong, B. T., \& Dong, N. T. (2001). Khai Quat Dia Diem Bai Ben (Dao Cat Ba, Hai Phong) (Excavation at Bai Ben (Cat Ba island, Hai Phong)). In Nhung phat hien moi ve Khao co hoc nam 2000 (New Archaeological Discoveries in 2000) (pp. 110112). Hanoi: Social Sciences Publishing House.

Fish, P. R. (1981). Beyond tools: Middle Paleolithic debitage analysis and cultural inference. Journal of Anthropological Research 37: 374-386.

Gould, R. A., \& Saggers, S. (1985). Lithic Procurement in Central Australia: A Closer Look at Binford's Idea of Embeddedness in Archaeology. American Antiquity 50: 117-136.

Hartenberger, B., \& Runnels, C. (2001). The Organization of Flaked Stone Production at Bronze Age Lerna. Hesperia 70: 255-283.

Hiscock, P. (1993). Bondaian Technology in the Hunter Valley, New South Wales. Archaeology in Oceania 28: 65-76.

Hiscock, P. (1994). Technological Responses to Risk in Holocene Australia. Journal of World Prehistory 8: 267-292.

Hiscock, P. (2001). Looking the Other Way: A Materialist/Technological Approach to Classifying Tools and Implements, Cores and Retouched Flakes, with Example from Australia. In S. McPherron \& J. Lindley (Eds.), Tools or Cores? The identification and Study of Alternative Core Technology in Lithic Assemblages. (pp. 198222). Newcastle-upon-Tyne: Cambridge Scholars Publishing.

Hiscock, P. (2006). Blunt and to the Point: Changing Technological Strategies in Holocene Australia. In I. Lilley (Ed.), Archaeology in Oceania: Australia and the Pacific Islands (pp. 69-95). Oxford: Blackwell.

Ingbar, E. E. (1994). Lithic Material Selection and Technological Organization. In P. J. Carr (Ed.), American Prehistoric Chipped Stone Tool Technologies (pp. 45-56). Ann Arbor, Michigan: International Monographs in Prehistory.

Jeske, R. J. (1992). Energetic Efficiency and Lithic Technology: An Upper Mississippian Example. American Antiquity 57: 467-481.

Knell, E. J. (2004). Coarse-Scale Chipped Stone Aggregates and Technological Organization Strategies in the Hell Gap Locality V Cody Complex Component, Wyoming. In C. T. Hall \& M. L. Larson (Eds.), Aggregate Analysis in Chipped Stone (pp. 156-183). Salt Lake City, Utah: The University of Utah Press.

Kuhn, S. L. (1990). Diversity within Uniformity: Tool Manufacture and Use in the 'Pontinian' Mousterian of Latium (Italy). PhD Dissertation, The University of New Mexico. 
Kuhn, S. L. (1995). Mousterian Lithic Technology: an Ecological Perspective. Princeton: Princeton University Press.

Morrow, J. E. (1996). The Organization of Early Paleoindian Lithic Technology in the Confluence Region of the Mississippi, Illinois, and Missouri Rivers. Ph.D Dissertation, University of Washington.

Nelson, M. C. (1991). The Study of Technological Organization. Archaeological Method and Theory 3: 57-100.

Nga, H. H., \& Hao, N. V. (1998). Tien su Ha Long (Prehistory of Ha Long). Hanoi: World Publishing House.

Odell, G. H. (2000). Stone Tool Research at the End of the Millennium: Procurement and Technology. Journal of Archaeological Research 8: 269-331.

Piperno, M. (1973). Micro-drilling at Shahr-i Sokhta; the Making and Use of the Lithic Drill-Heads. In N. Hammond (Ed.), South Asian Archaeology (Papers from the first international conference of South Asian archaeologists held in the University of Cambridge) (pp. 119-129). London: Duckworth.

Rosen, S. A. (1995). Microlithic Drills from the Carnel Site, Mitzpe Ramon. Journal of the Israel Prehistoric Society 26: $148-158$.

Shott, M. J. (1986). Technological Organization and Settlement Mobility: an Ethnographic Examination. Journal of Anthropological Archaeology 42: 15-51.

Shott, M. J. (1989). Technological Organization in Great Lakes Paleoindian Assemblages. In C. J. Ellis \& J. C. Lothrop (Eds.), Eastern Paleoindian Lithic Resource Use (pp. 221237). Boulder, Colorado: Westview Press.

Stiner, M. C., \& Kuhn, S. L. (1992). Subsistence, Technology, and Adaptive Variation in Middle Paleolithic Italy. American Anthropologist 94: 306-339.

Tankersley, K. B. (1991). A Geoarchaeological Investigation of Distribution and Exchange in the Raw Material Economies of Clovis Groups in Eastern North America. In A. Montet-White \& S. Holen (Eds.), Raw Material Economies among Prehistoric Hunter-Gatherers (pp. 285-303). Lawrence, Kansas: University of Kansas.

Thanh, T. D. (1998). Lich Su Dia Chat Vinh Ha Long (Geological History of Ha Long Bay). Hanoi: World Publishing House.

Wiant, M. D., \& Hassen, H. (1985). The Role of Lithic Resource Availability and Accessibility in the Organization of Lithic Technology. In S. C. Vehik (Ed.), Lithic Resource Procurement: Proceedings from the Second Conference on Prehistoric Chert Exploitation (pp. 101-113). Carbondale, Illinois: Center for Archaeological Investigations, Southern Illinois University.

Yerkes, R. W. (1983). Microwear, Microdrills, and Mississippian Craft Specialization. American Antiquity 48: 499-518. 